
UNITED STATES DEPARTMENT OF THE INTERIOR

Harold L. Ickes, Secretary

FISH AND WILDLIFE SERVICE

Ira N. Gabrielson, Director

\title{
Circular 3
}

\section{MAMMALS AND BIRDS \\ OF ALASKA}

\author{
BY \\ FRANK DUFRESNE
}

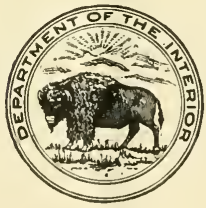

UNITED STATES

GOVERNMENT PRINTING OFFICE

WASHINGTON : 1942 
WILDLIFE not only provided the main incentive for W the colonization of Alaska by the Russian discovererof two centuries ago, but under the Stars and Stripes since 1867 has continued to play a leading role in the development of the Territory. This rich resource is now being managed in such way as to guarantee its preservation indefinitely. Other natural resources of Alaska are the fisheries, minerals. and forests, but obviously for years to come great areas of the Territory will be best adapted for the production of wildlife for human enjoyment and utilization. 


\title{
MAMMALS AND BIRDS OF
}

\author{
I3y Frank Dufresne
}

Exccutive Officer, Alaska Game Commission, and Resident Representative of the

Fish and II ildlife Service

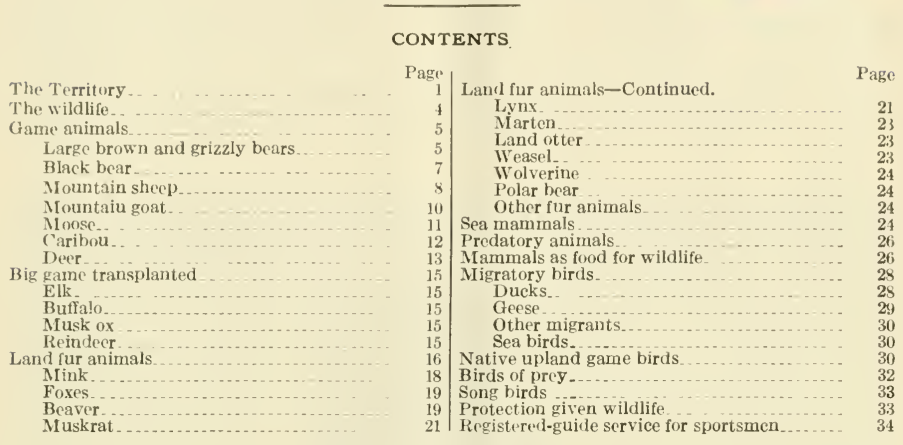

THE TERRITORY

T T IS SIGNIFICANT that the only objects of value that the Russian 1 discoverers of Alaska took back to Asia two centuries ago were furs. The lustrous pelts of the sea otter found instant favor with royalty and were the driving urge that brought about the first white colonization of the Territory. The fur resources have continued to play an important part in the development of Alaska, together with an abundance of a variety of fishes and big-game animals and of a few widely distributed game birds. These furnished a dependable source of supply of food for the early explorers and settlers, and even now if the fur and game supply should be depleted, large parts of Alaska could not support a human population.

Alaska, with its 590,884 square miles, is one-fifth the size of the entire 48 States. Its great expanse will be appreciated by comparing a map of the Territory with one of the United States, which shows that north and south Alaska would extend from Canada to Mexico, and east and west from Georgia to California (fig. 1). It is twice the size of Texas and nearly 120 times that of Rhode Island. Its human population of 72,524 is scattered at the rate of about 1 to every 8 square miles, a density that is readily compared with 44 per square mile for the 48 States, 24 for Texas, and 674 for Rhode Island. Included in the Territory are more than 3,000 islands, 1,100 of which are in the Alexander Archipelago in southeastern Alaska. 'The total coast line is about 26,000 miles. 
This extensive Territory may be divided into four broad geographical regions-the Pacific Mountain Region, the Central Plateau, the Arctic Plains, and the Aleutian Islands-which present striking contrasts in surface, climate, vegetation, mineral resources, and agricultural possibilities.

The Pacific Mountain Region is a continuation of the rugged mountainous district of western United States and British Columbia. It is an area of high relief and of great valleys that were gouged out during the ice age. Hundreds of snow-capped peaks rise to high altitudes. Scores of immense glaciers descend to the coast from extensive ice fields. The summers are cool and damp and the winters compara-

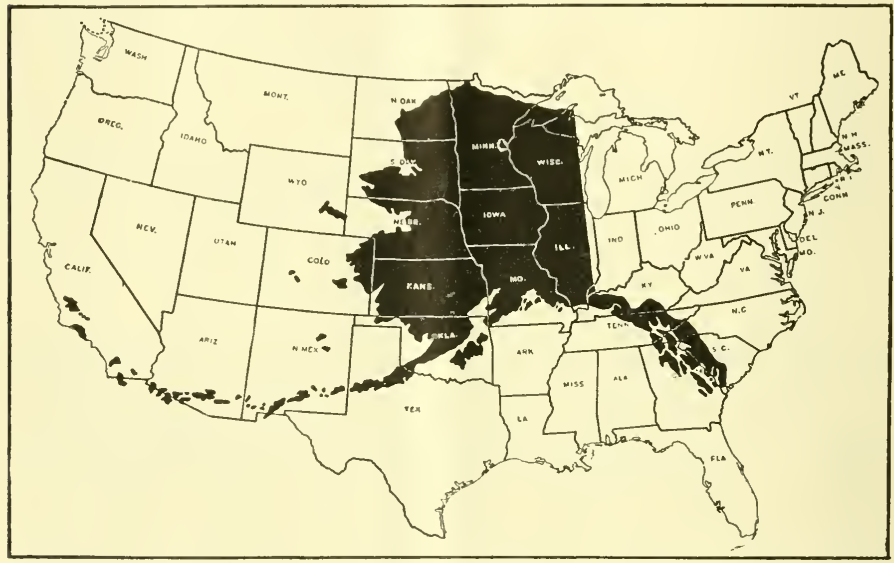

B3231M

Figure 1.- The size of Alaska is readily appreciated by noting the extent of a map of the Territory superimposed on a like-scale map of the United States.

tively mild. Precipitation is heavy, ranging from 60 to 140 inches annually. The lower mountain slopes are heavily forested with hemlock, spruce, and giant cedar.

The Central Plateau, comprising about two-fifths of the Territory, is relatively low in relief and is characterized by flat-topped highlands; it includes the basins of the Yukon and Kuskokwim Rivers. This is a country of short, warm summers, with 18 to 20 hours of sunshine daily, and of long, cold winters. The precipitation is seanty, varying from 9 to 19 inches, including a relatively slight snowfall. Twothirds of the area is in forests of small open growths. Pasturage is afforded for moose and caribou. Situated just south of the center of the Territory, snow-covered Mount McKinley (fig. 2), towering 20,300 feet, is the highest peak on the continent. The Yukon, second 
longest river in North America, already 800 miles from its source in Yukon Territory when it reaches the boundary, meanders an additional 1,500 miles through Alaska before pouring its silt-laden, gray flood into Bering Sea, where together with the Kuskokwim, it forms a vast delta more than 10,000 square miles in extent that furnishes one of the most ideal spots on the continent for nesting waterfowl.

The Arctic Plains Region, of actual aretic conditions, constitutes about one-sixth of the Territory. Its low, rolling hills and plateaus are dissected by northward-flowing rivers and streams. Its climate is cold and arid, with only about 6 to 8 inches of precipitation. The winters are long, dark, and bitter cold and the summers short and

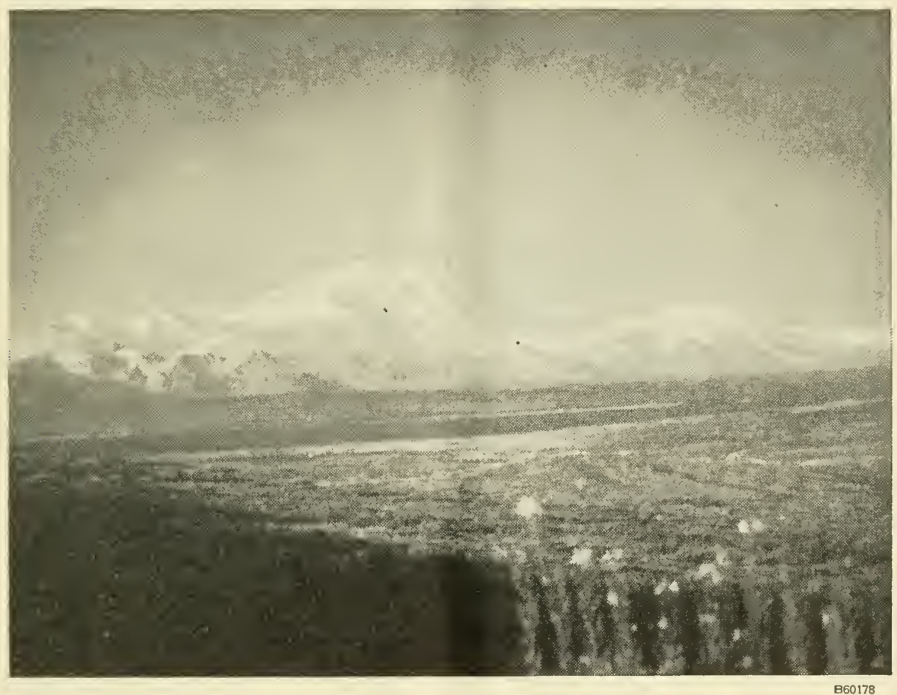

Figure 2.-Mount McKininley, Alaska, altitude 20,300 feet, the highest peak in North America. (Photo by Ira N. Gabrielson.)

cool. Even so, the period of continuous sunshine, extending from May until August, induces a luxuriant growth of mosses, bright flowers, lichens, and grasses, though the soil cover thaws only to a depth of about a foot. Timber is thin or wanting, and willows, some of them only a few inches high, become the predominant tree growth in the Arctic drainage.

The Aleutian Islands Region extends westward from the tip of Alaska Peninsula for 1,100 miles in a long are that places the outermost island of Attu within 600 miles of Kamchatka and the Japaneseowned Kurile Islands. The Aleutians may be described as treeless, 
fog-bound, volcano-studded mountain tops protruding from the sea. Sparsely populated, the chief wildlife interests here are the immense colonies of sea birds and the remnants of a once abundant herd of sea otters, now slowly increasing as a result of protection. Blue foxes, transplanted to islands held under lease from the Government by the Aleut communities and by a few old-time settlers, are the only land mammals on many of the islands. Northward, some 200 miles away, are the mist-shrouded Pribilof Islands, where a valuable herd of more than 2,000,000 fur seals receives special care from the Government of the United States, through the agency of the Fish and Wildlife Service.

Alaska is a rugged, primitive land. Its main assets are its fisheries, wildlife, minerals, and forests. Its human population has changed but little during the past 30 years. Recently, however, the defense program has caused an appreciable increase in the population. It is obvious that great parts of the Territory may best be used for wildlife production for many years to come.

\section{THE WILDLIFE}

Natural erosion and mining operations have uncovered widespread evidence of pre-ice-age mammal inhabitants of the Territory. Some of the skeletal material includes remains of the moose, elk, musk ox, caribou, wolf, bear, and squirrels that have living representatives in today's wildlife. Extinct species include the mastodon, mammoth, horse, camel, giant bison, puma, and sabre-toothed tiger. These fossil remains indicate a former climate somewhat milder than that of today and show also that it permitted the growth of redwood, elm, grape, and other plants not now found in the Territory. As with the faunal life, there are connecting links between the growths of the pre-ice-age and modern times in the willows, birches, and cottonwoods.

The abundance, variety, and distinctive characteristics of its present fauna give Alaska a high place among the important wildlife regions of the world. No other feature of the Territory is of so much interest to the people of the United States, and it draws north a constantly increasing number of hunters, naturalists, photographers, painters, tourists, and sightseers. Both sound economies and conservation sentiment dictate that a definite and prominent place be given to the perpetuation of an abundant supply of wildlife in the drafting of any plans looking toward the future development of the Territory. The great decrease in the wildlife of the Western States, as unplanned and unrestrieted settlement progressed across the country, and the strenuous efforts now being made to restore some small fraction of this national resource at the insistence of a growing multitude of conservationists and outdoor recreationists, clearly indicate that advance planning for Alaskan wildlife is necessary and should be kept in mind 
at this time while the resource is still almost intact and before powerful conflicting interests arise.

\section{GAME ANIMALS}

Alaska's wildlife falls into three main classes: the big game, the fur animals, and the birds. Best known of the big game are the bears, which are found in such exceptional profusion as to suggest that Nature fairly outdid herself in the numbers and varieties ereated. Included in these are the coastal brown bears, represented by several subspecies; the closely allied grizzlies of the interior mountain ranges;

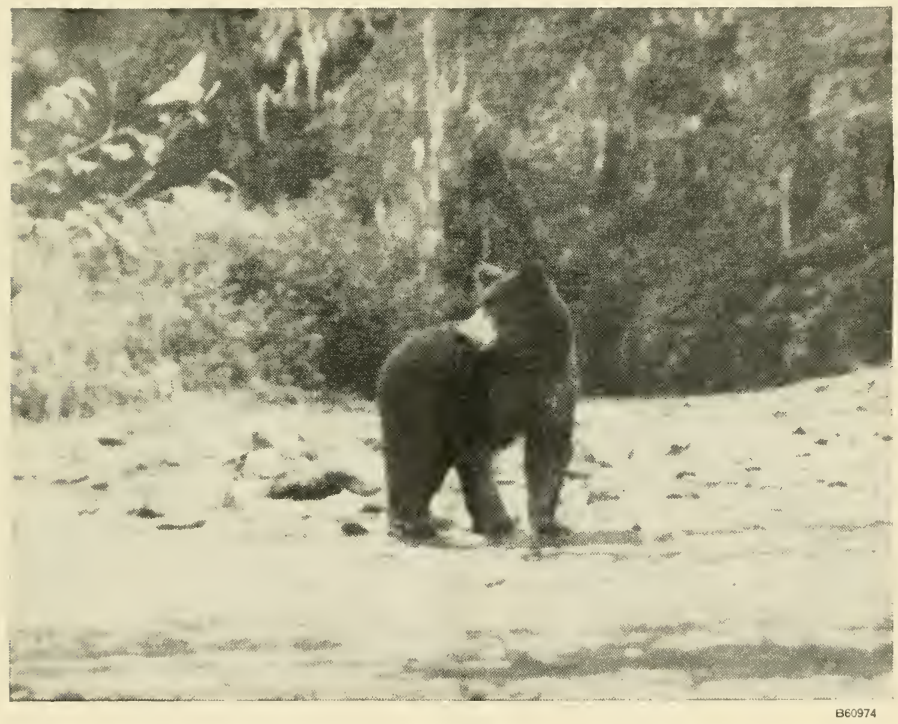

Figure 3.-Alaska brown bear on Admiralty Island salmon stream. (Photo by Jos. Yolo.)

the black bears, including the brown and glacier bear color phases; and lastly, the polar bears, snow-white visitors to the Arctic and Bering Sea coasts from the poiar ice packs. Among other big-game animals are the moose, caribou, deer, mountain sheep, mountain goat, and as introduced species, the elk, buffalo, musk ox, and semidomesticated reindeer.

\section{LARGE BROWN AND GRIZZY BEARS}

Holding first place in the public interest is the Alaska brown bear (fig. 3), largest carnivore on earth. Monarch of all its surveys in its $423674^{\circ}-42-2$ 
wilderness kingdom, this bear grudgingly gives way only to man and his high-powered rifle. Even in the face of such odds it occasionally puts up a great fight. Perhaps it is this courageous trait that has made its shaggy hide such a desirable trophy and taking its photograph so memorable an experience. Although these giants of the forests have been sadly decimated in the States, the big brownie and its cousin, the grizzly, still roam vast areas along the salmon streams near the coast and among the mountain ranges of the central parts of Alaska. Altogether, not less than 200,000 square miles (fig. 4) are occupied by these bears, and since the sale of their hides was

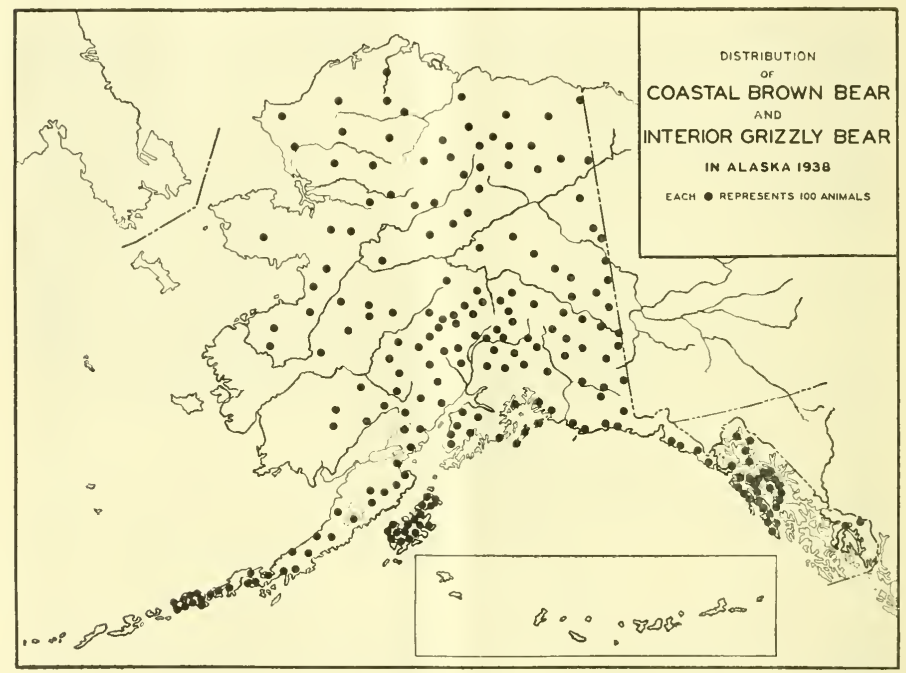

Figure 4.-Distribution of large brown and grizzly bears.

prohibited by Federal law several years ago, they have gradually increased in numbers. The population of coastal brown bears has been placed at about 8,500 , and that of bears of the interior at 10,000 .

As seen in the ficld, there is a remarkable similarity in appearance between the large brown and the grizzly bears, but under close examination they are found to difler in color, claws, skull, and teeth. The pelage of the brown bear is more uniform in color, with less admixture of golden or silver-tipped hairs, and is generally much darker than that of the grizzly. The Shiras brown bear found on Admiralty Island is almost coal black. The claws of the brown bear are shorter than those of the grizzly, and more curved, darker, and rougher, and the skull is more massive. Oceasional brown bears, 
however, have a stronger resemblanee to the grizzly type than to that of their own species. Whoever attempts to identify brown and grizzly bears in Alaska faces a puzzling task for, according to the authority on the subject, C. Hart Merriam, there are no fewer than 28 species and subspecies in the Territory.

Bears emerge from hibemation late in $\Lambda$ pril or in May and mate in June of every other year. In summer, when salmon are spawning, they form the favorite fool of brown bears, but at other seasons grasses, roots, and berries are staples. The grizzly bear inhabits the mountains and supplements its fare with a diet of ground squirrels,

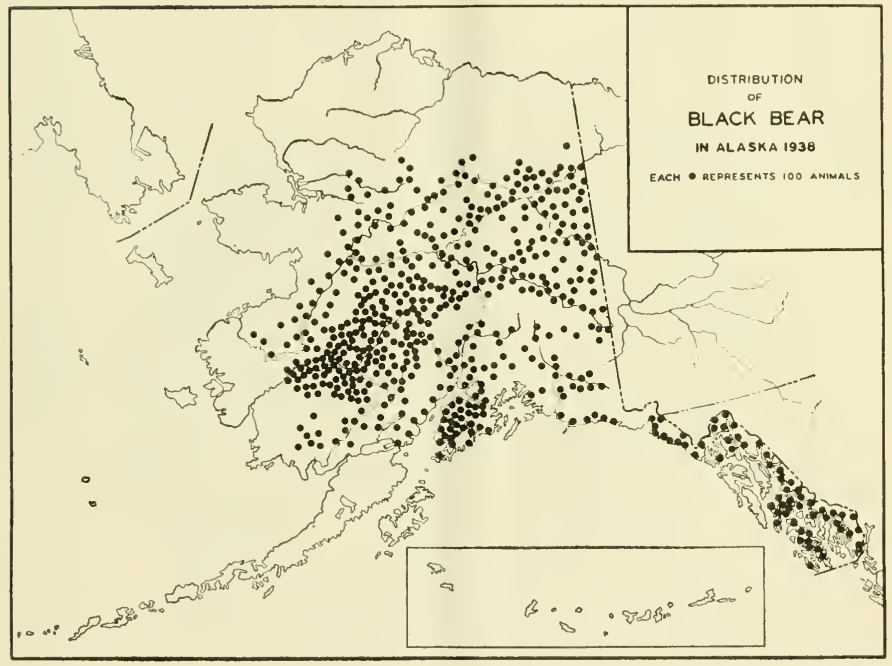

Figure 5.--Distribution of the black bear.

marmots, and other animals that it may kill or find dead. In October and November the long hibernation begins, and late in January or early in February, one to four cubs are born.

The protection given brown and grizzly bears in Alaska is at present adequate. In addition to certain areas that are given special management with a view to preservation of the bear population, sanctuaries where no hunting is permitted have been provided, with an aggregate area of 13,416 square miles.

\section{BLACK BEAR}

Black bears, ranging over at least three-fifths of the land area of Alaska (fig. 5), have shown remarkable ability to adapt themselves to 
the ways of man. They are fortunate in that the value of their hides is so low as to offer little incentive for anyone to take them and in that their flesh is inedible to most people because of their summer and fall diet of spawning salmon. Their estimated number is about 75,000 in Alaska, where they are found in several color variationsdark brown and colored specimens oceurring in the same family with black animals, and in the glaciated sections of southern Alaska an occasional "bluc," or glacier, bear being seen (fig. 6).

In many parts of the Territory the black bear is reputed to kill moose calves, which habit, added to its destruction of food eaches

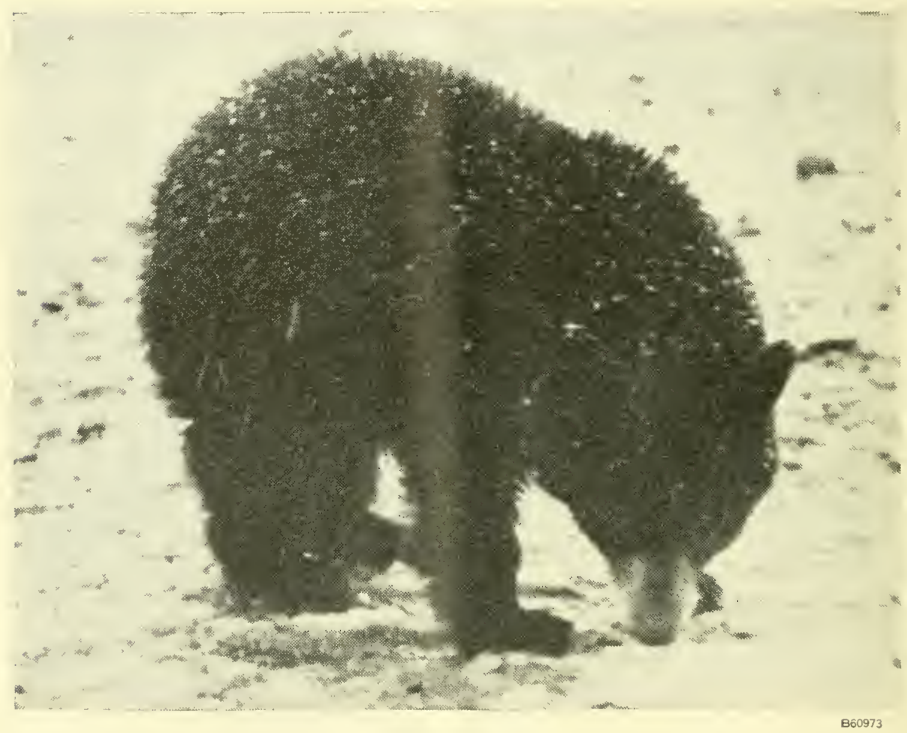

Figure 6. - Black bear on Upper Copper River late in fall. (Photo by Clarence J. Rhode.)

and its habit of entering cabins, tends to place bruin in the muisanee class. In the southeast, however, the black bear is looked upon with more favor. On refuges aggregating 3,864 square miles, no hunting is permitted.

\section{MOUNTAIN SHEEP}

The only white mountain sheep in any of the United States possessions are found in Alaska (fig. 7), where they are believed to number between 30,000 and 40,000. These sheep can be found in most of the high mountains that are sheltered from wet coastal storms in their 70,000 square miles of range, which extends from the Kenai Peninsula 


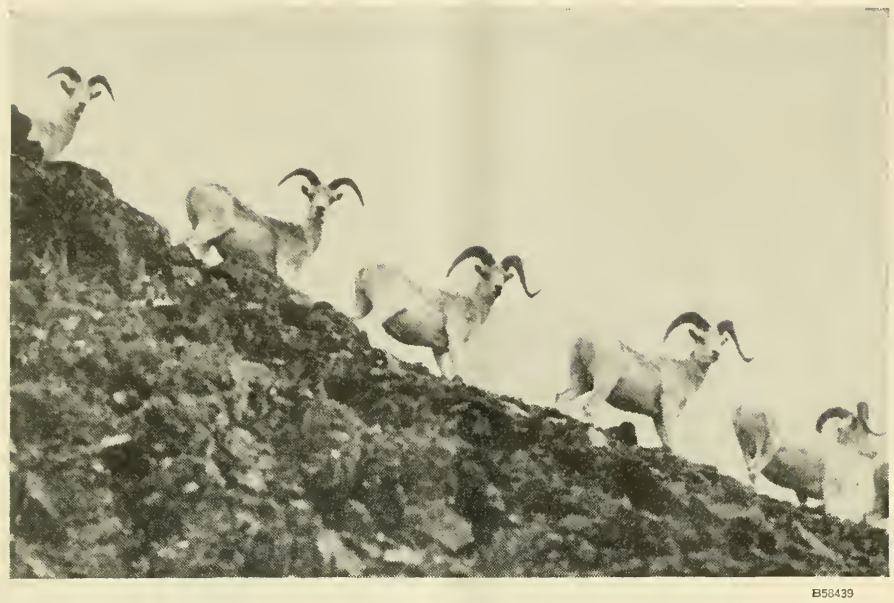

Figure 7.- White, or Dall, mulntain sheep, Rainy Pass. (Photu by A. M. Crocker.)

northward and eastward to the Canadian boundary (fig. 8). Probably the largest herds of bighorns now in existence in North America live in the Brooks Range north of the Yukon, and these sheep are also plenti-

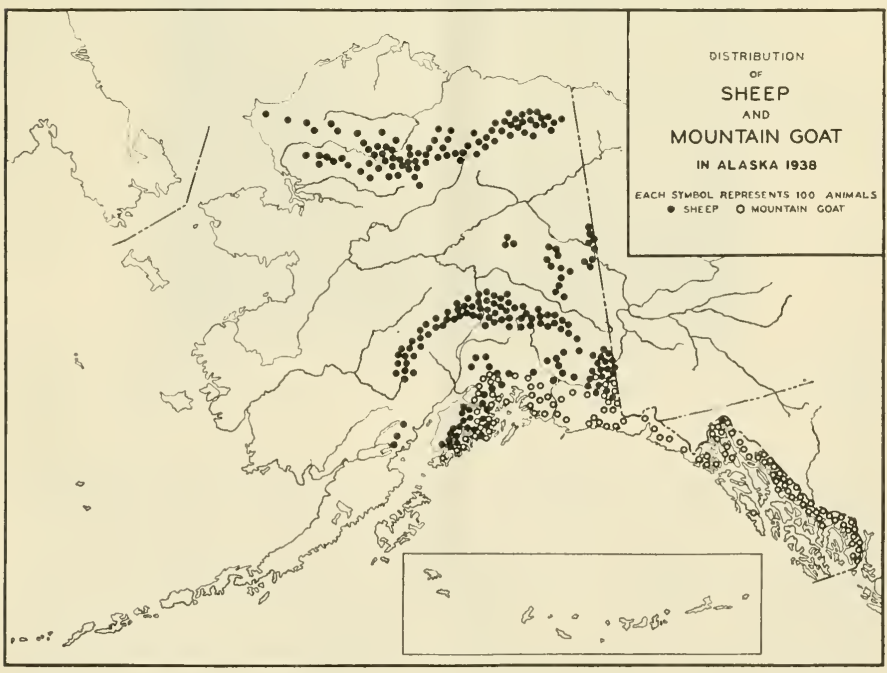

B8273M

Figure 8.-Distribution of the mountain sheep and the mountain goat. 
ful in the Nutzotin and Wrangell Mountains northwest of Cordova. To safeguard the species, 3 inviolate sanctuaries, aggregating 5,096 square miles, have been set aside.

\section{MOUNTAIN GOAT}

The home of the shaggy white mountain goat is among the cliffs and crags of heavily glaciated mountains bordering the coast line. This bewhiskered patriarch prefers the storm-swept crests fronting

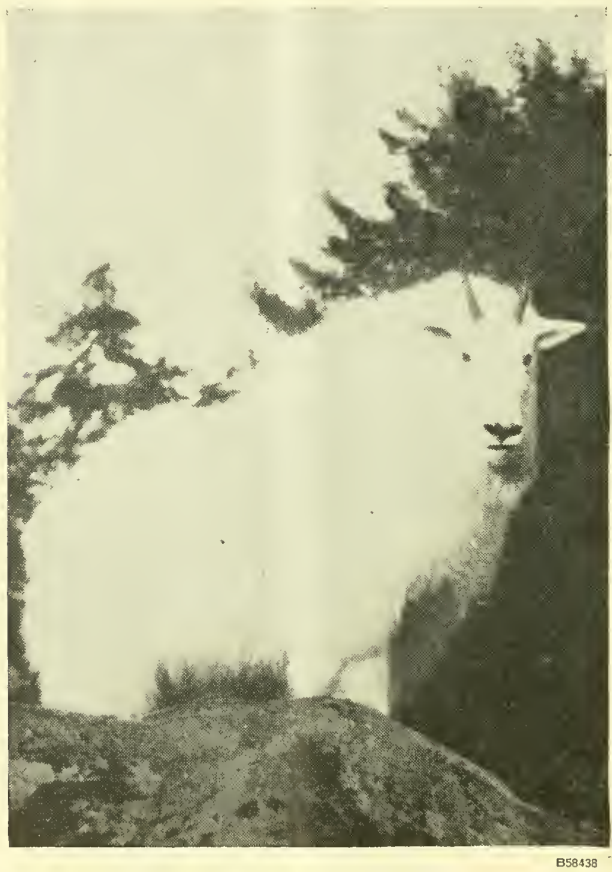

Figure 9.-Mountain goat transplanted on Baranof Island. (Photo by E. M. Goddard.)

the salt water between Portland Canal and the head of Cook Inlet. The total area of its habitat in Alaska is about 37,500 square miles (fig. 8), and the estimated population is 12,500. Baranof Island, in southeastern Alaska, was successfully stocked with these wild goats a few years ago (fig. 9). Although never regarded as abundant in the Territory, the mountain goat, by its way of living, is assured protection from all but the hardiest of human hunters. Wolves and bears 
prey upon it to some extent, but it is believed that avalanches, which are a common feature of its chosen terrain, destroy more mountain groais than any other one natural cause. Sanctuaries, aggregating 7,444 square miles, assure the preservation in goodly numbers of this interesting animal.

\section{MOOSE}

The Alaska moose is the largest of its kind on earth, the bulls attaining a weight of more than 1,400 pounds and having an antler spread exeeding 6 feet. The willow, predominant tree growth in the Territory, is its favorite food and enables it to pasture over at least

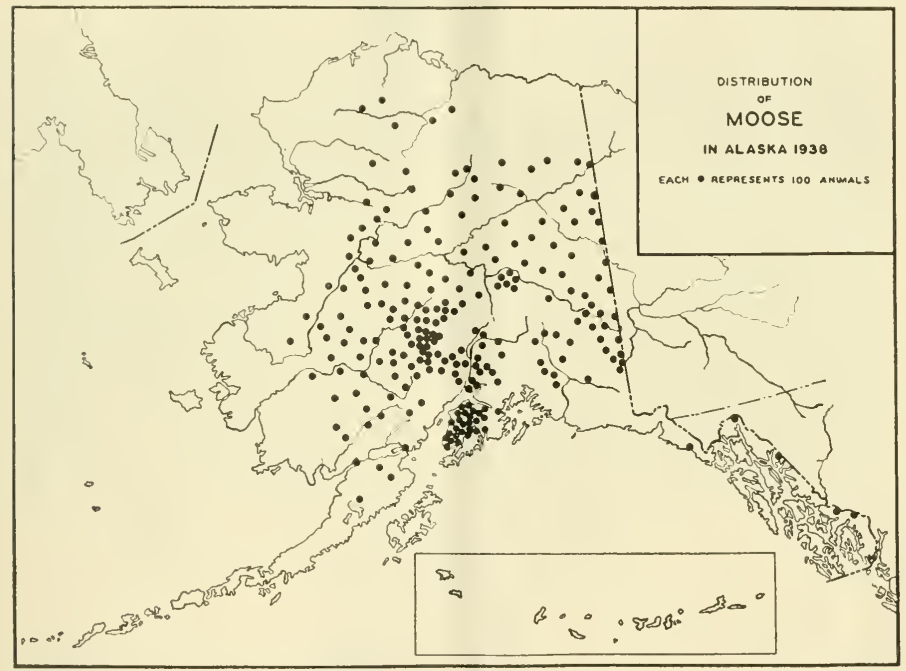

Figure 10.-Distribution of the Alaska moose.

B8271M

240,000 square miles of brush and open forest lands (fig. 10). Although most abundant on Kenai Peninsula (fig. 11) and in Rainy Pass, the moose has extended its range woll out onto the treeless Alaska Peninsula and has also been found within a few miles of the Arctic coast. Its chief natural enemy is the wolf. At long intervals when severe winters coincide with the cyclical peak of the snowshoe hare, which competes with the moose for food in the willow patches, many of these huge creatures die of starvation. The rutting season occurs in September and October. The young, one or two, are born late in May or early in June. On 11,307 square miles of sanctuary provided for the perpetuation of these great animals no hunting is permitted. 


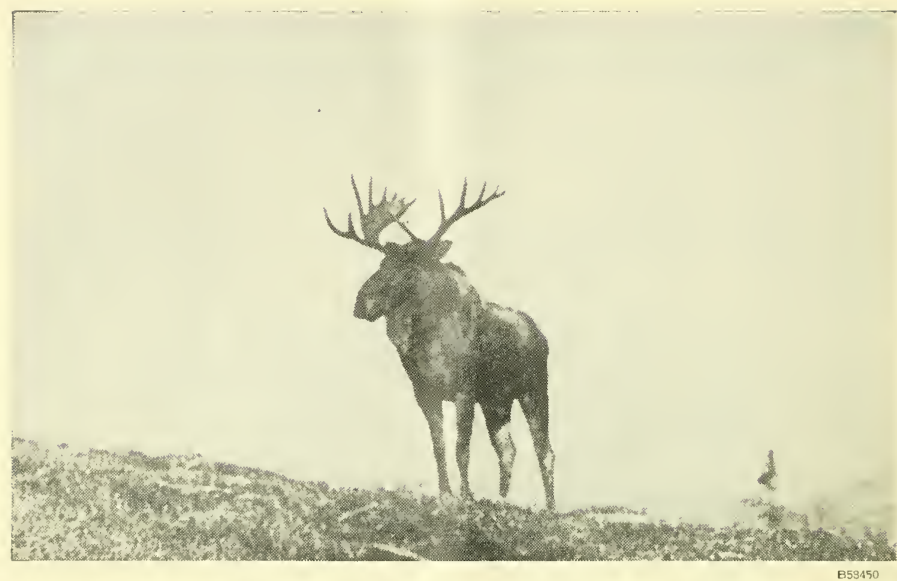

Figure 11.-Alaska moose-lord of the Kenai. (Photo by Andrew A. Simons.)

\section{CARIBOU}

The caribou unquestionably is the most abundant big-game animal in Alaska. Bulls may attain a weight of 500 to 600 pounds, and their wide-spreading antlers, with the characteristic brow tines reaching

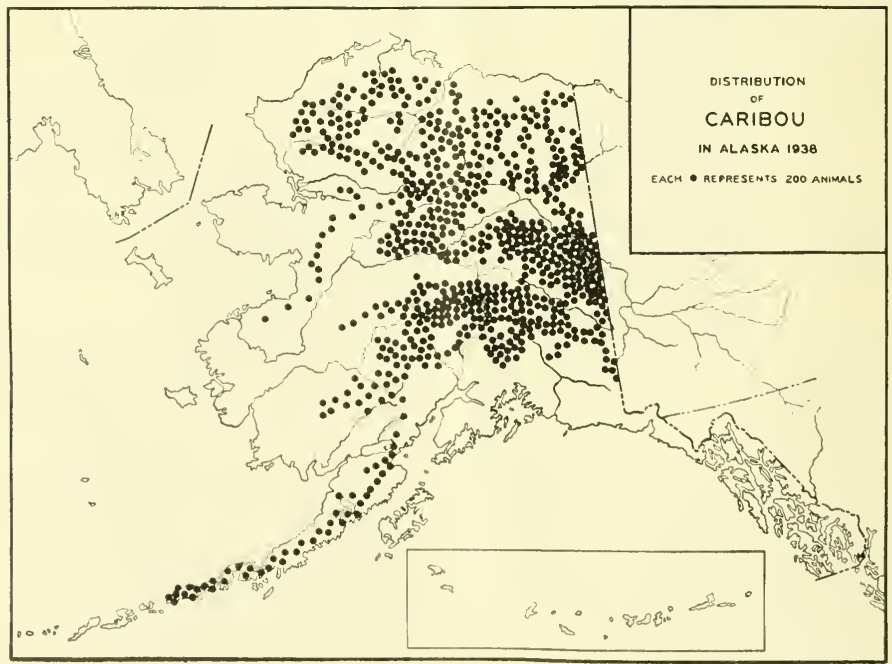

F1GURE 12.-Distribution of the caribou. 
down and forward across the face, give the species a distinctive appearance. The races include both mountain and barren-ground types and include the Stone, Grant, and the Point Barrow caribou, as well as the McGuire race, which oceurs along the Mlaska-Yukon boundary. The animals are found mainly among the higher plateatus of the Alaska and contiguous ranges, although tens of thousands are supported on the Brooks Range north of the Aretic Circle. $\Lambda$ isolated herd of the Grant variety roams the Alaska Peninsula from Katmai National Monument to and including L'nimak Island. Altogether some 250,000 squire miles (fig. 12) in Alaska are roved by these nomadic animals during their annual wanterings (fig. 13). Their favorite foods are

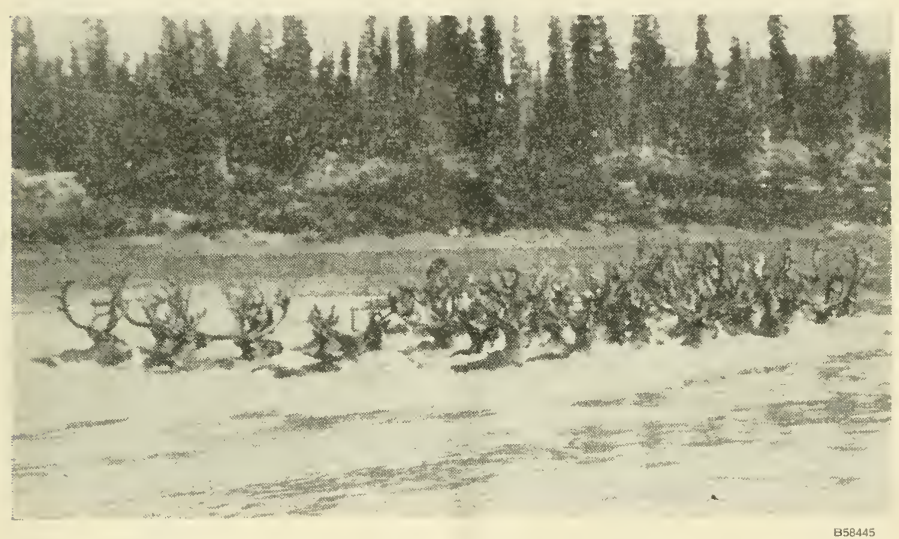

Figcre 13.- Herd of caribou bulls swimming the Yukon River. (Photo by Frank Dufresne.)

lichens, or "reindeer moss," although they consume much browse also in summer. On refuges provided for the caribou, aggregating 8,829 square miles, no hunting is permitted.

\section{DEER}

In the heavily forested regions of southeastern Alaska, where the average annual precipitation is 60 to 140 inches, lives the only true deer indigenous to the Territory. The Sitkan black-tailed deer (fig. 14), numbering about 40,000 individuals, occupies about 12,000 square miles of range among the islands and also a narrow strip of the mainland shore line from Dixon Entrance to the Gulf of Alaska (fig. 15). It has been transplanted with excellent results to the Prince William Sound islands. This deer is rather small and, being at the extreme north of deer range in North America, it often suffers losses during serere winters. Deep snows and sharp cold, such as oecur $423674^{\circ}-42-\therefore$ 


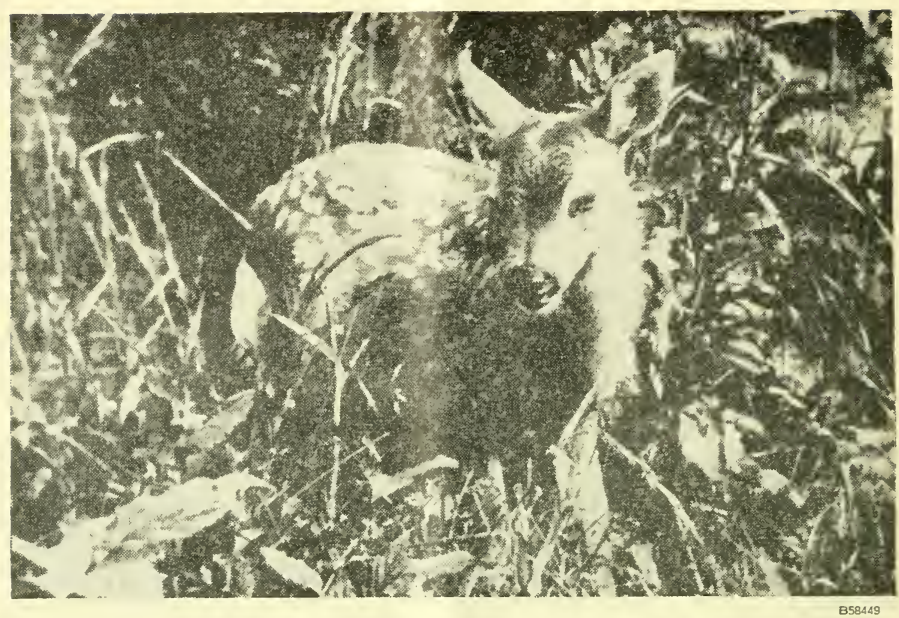

Figure 14.-Fawn of Sitkan black-tailed deer. (Photo by Mrs. B. B. Ficken.

every 5 or 6 years, drive the deer to the beach line, where they require special protection from wolves as well as from poachers. Refuges of 4,860 square miles have been provided, where the animals enjoy complete protection.

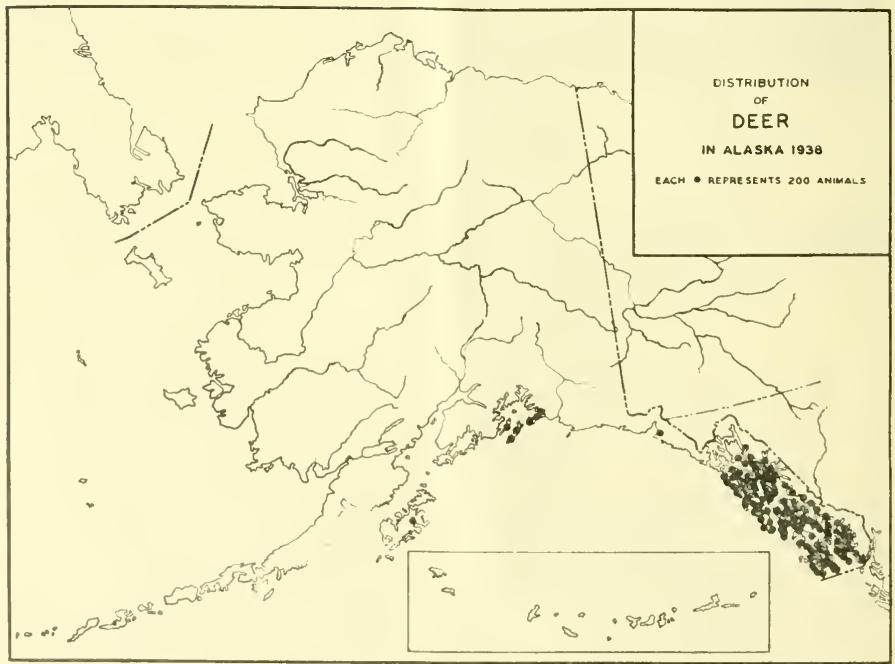

Figuke 15.- Distribution of the Sitkan black-tailed deer.

$83268 \mathrm{M}$ 


\section{BIG GAME TRANSPLANTED}

ELK

Experiments have been made in the introduction of game animals that could subsist upon certain foods not much utilized by native Alaskan species. A shipment of 8 Roosevelt elk, liberated on Afognak Island in 1927 , has increased to a present herd of 200 or more fune, healthy animals. It is believed that the larger neighboring island of Kodiak will at sone time be naturally stocked from this herd.

\section{BUFFALO}

Another interesting and successful transplanting experiment was that of moving 23 buffaloes in 1928 from the National Bison Range, in Montana, to the Big Delta section southeast of Fairbanks on the Tanana River (fig. 16). From the rery first these animals showed

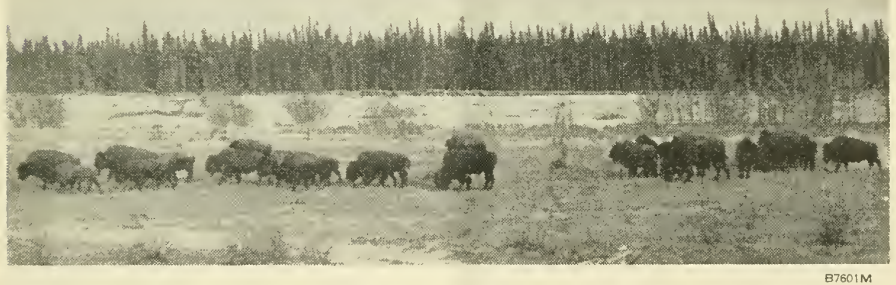

Firiure 16.- Buffalo reintroduced into Alaska-Big Delta section. (Photo by Calvin Cripes.)

complete ability to care for themselves. The herd now numbers nearly 300 animals, has withstood the severest winter weather, and is increasing at a gratifying rate.

\section{MUSK OX}

The reintroduction of musk oxen to Alaska, after an absence of about 75 years, was accomplished in 1930. At one time these shaggycoated (fig. 17) ruminants appear to have been fairly well distributed along the Arctic coast, but owing to lack of fear of man they were exterminated by the early whalers and traders. In 1930, 34 individuals, captured in Greenland, were brought to Fairbanks. The herd was later placed on Nunivak National Wildlife Refuge, in Bering Sea, where it has increased to more than 90 animals.

\section{REINDEER}

Though not strictly classed as wildlife, the reindeer, semidomesticated relative of the caribou, may be mentioned as one of the carliest 
and most successful examples of transplantation in Alaskan history. For the purpose of proviling a dependable source of meat supply to the Eskimos and other residents of the northwestern parts, a total of 1,280 remdeer were bronght in from Siberia during the 12 years 1891 to 1902 . Their increase for a few years was phenomenal, and despite heavy local use and various attempts at commercialization the herds today are believed to be well established in the fauna of the Territory. The general distribution is along the tundra from Bristol Bay northward to Barrow.

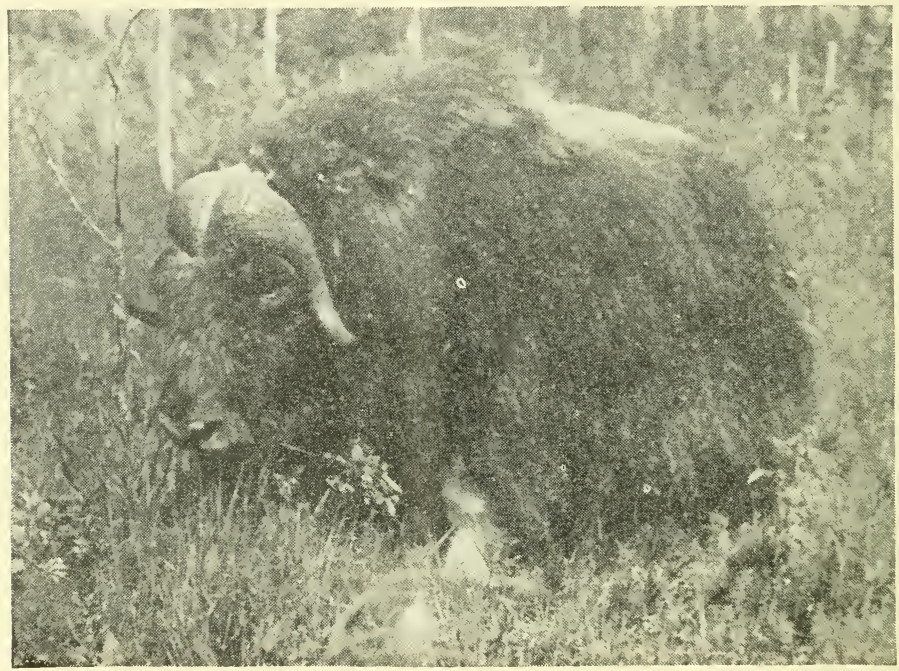

B58452

Flgure 17.-Reintroduced musk ox-near College, in 1935, before shipment of herd to Nunivak Island. (Photo by Frank Dufresne.)

\section{LAND FUR ANIMALS}

Alaska's 20-odd varieties of land fur animals are the basis of the major part of the income earned by hundreds of Indians, Eskimos, and Aleuts. Although many of these native people have developed other ways of making a living, it should be understood that trapping, hunting, and fishing nust be the mainstay of their existence now and for a long time to come. Numerous professional white trappers, old-time residents, and homesteaders also measure good times by the numbers and prices of the furs they take.

Revenues derived from the gathering of furs in Mlaska are of such impertance as to rank the business thirel among the leading industrice, it being exceded only by fisheries and mining. During the 83 
years of oceupaney by the Russians (1784-1867), furs to the value of $\$ 45,000,000$ were shipped to the mother country. Since its purehase by the United States in 1867 for $\$ 7,200,000$, Alaska has exported furs valued at more than $\$ 125,000,000$, exclusive of the large take of fur seal pelts gathered under Govermment supervision on the Pribilof Islands. Special consideration is due the fur industry because of the class of people dependent upon it. Probably 15,000 natives, women and children included, share in the average annual return of more than $\$ 2,300,000$ (table 1) from the sale of pelts; they also use large quantities of furs for garments and bedding.

TABLE 1.-Yearly average number and value of land furs exported from Alaska over a 16-year period

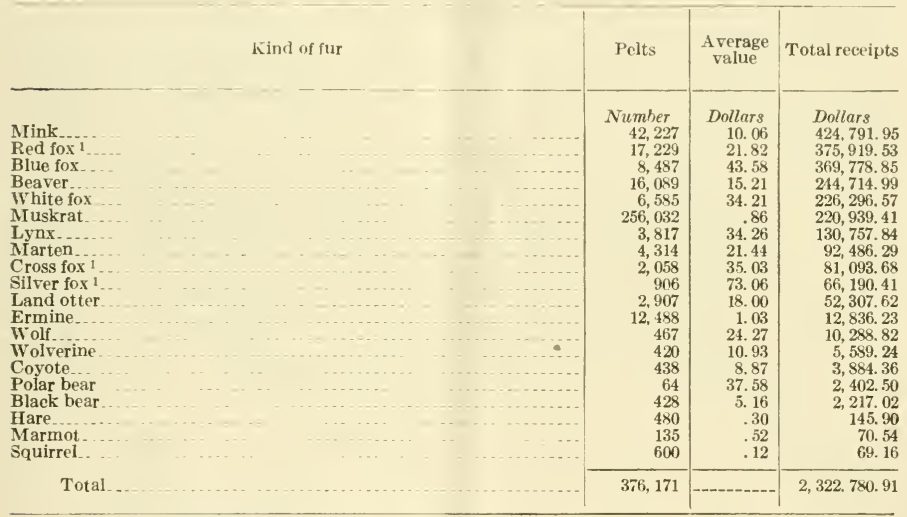

${ }_{1}^{1}$ Red, eross, and silver foxes all belong to the same speeies.

Lately there has been a marked tendency for people to move to Alaska "for the purpose of making their living by hunting and trapping," in the Daniel Boone spirit. This class of settler is reluctantly, but positively, warned against the undertaking. Every part of Alaska is already being thoroughly trapped, and every species of fur animal is being cropped as elosely as is consistent with maintaining a safe breeding supply, and the merchandizing of wild-caught furs will stand no further expansion. There is, however, ample opportunity for persons with some capital to engage in ranch raising minks and blue and silver foxes. Already 300 licensed fur farmers are operating in the Territory, and at Petersburg a Territorial experiment station is studying the feeding, breeding, and managing of fur animals and related problems. Fur farming is an important and valuable adjunct to the fur industry and to the conservation of fur animals in the wild. 
The ranching of blue foxes on the Aleutian Islands and some of the smaller islands of southeastern Alaska has now beeome an established industry. The average output from ranches is about 8,000 pelts annually, in addition to which ehoice breeding stock is exported to many parts of the world. A few silver foxes also are raised in the Territory. About half of all the fur farmers are more interested in minks than in any other fur animals. The produetion of their dark, silky pelts has steadily inereased during the past few years. Fish, a satisfactory basic food, is plentiful, and the elimate is conducive to growing peltries of the high grade for which the Alaskan wild-caught furs have won world-wide recognition. The ranchers are experimenting also with the marten, beaver, white fox, land otter, fitch, raccoon, and muskrat.

Ample locally produced breeding stock is available for the equipment of fur ranches. The Alaska Game Commission maintains a list of all licensed fur farmers, which will be mailed free to persons interested.

\section{MINK}

The most valuable of all Alaskan land fur animals is the mink, the peltries of which are exported to the value of nearly half a million dollars each year. The mink is widespread in the wild (fig. 18), and is one of the few fur animals that lend themselves readily to pen propagation. Alaska minks are large in size and exeellent in fur quality.

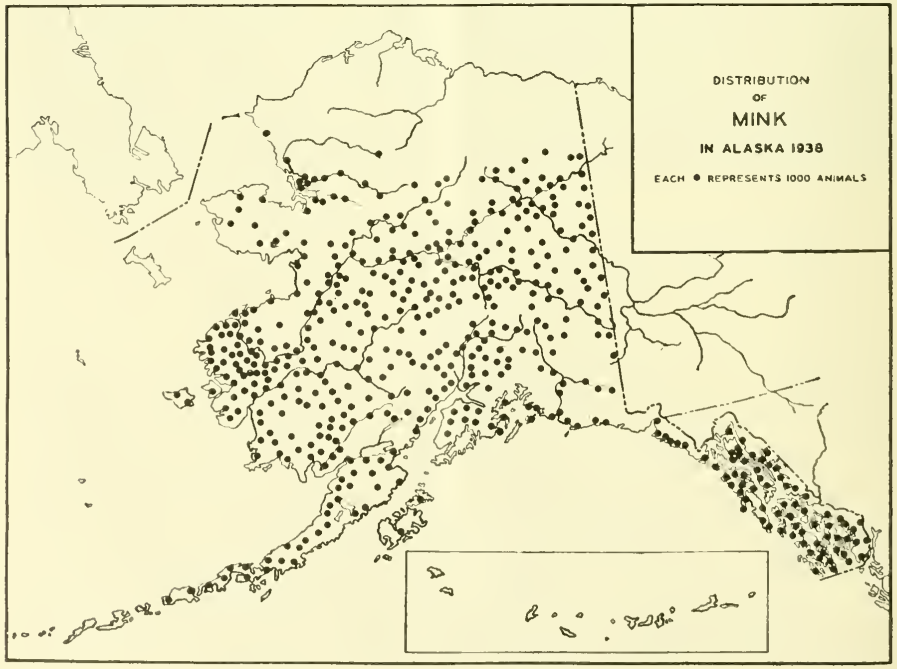

Figule 18.--Distribution of the mink. 
FOXES

There are 2 distinct species and 5 different color varieties in the Alaska foxes. The red fox produees cross variants in the ratio of about 1 to $S$, and silvers about 1 to 20 . Members of the genus Tulpes (red foxes) are found in nearly all parts of the Territory (fig. 19), being missing only from the timbered islands off the southern coast. The Aretic foxes (Alopex) are represented by the white fox of the northwest coast and the blue fox (fig. 20) of the Alentian Island region. Foxes of this genus are smaller than red foxes. They are beachcombers, seldom traveling inland more than a few miles. At times,

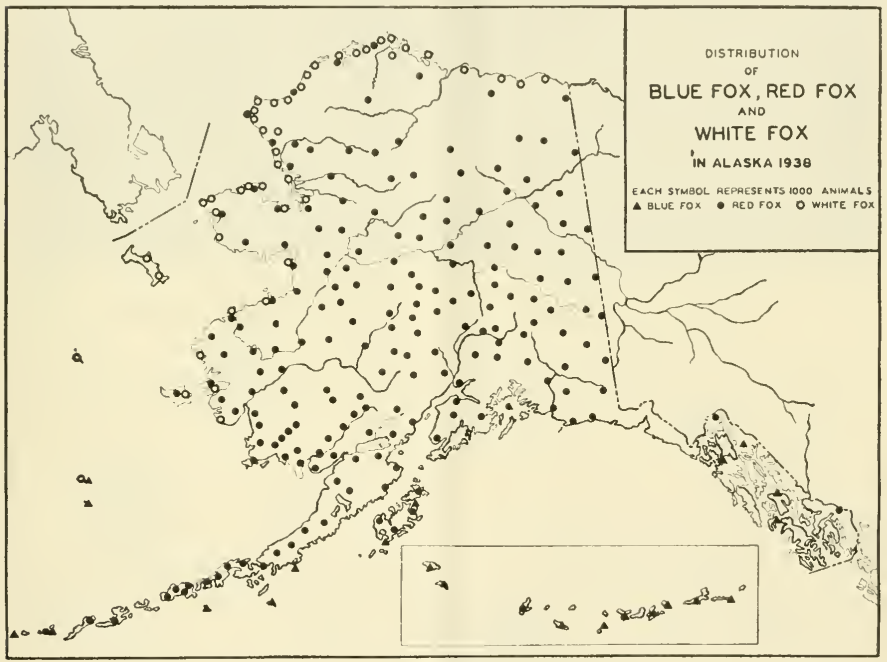

Figure 19.-Distribution of foxes.

great numbers of white foxes roam for long periods far out on the floating ice of the Arctic seas. The blue foxes have long been raised on various islands in the Aleutian Chain and in southeastern Alaska; in fact only a very small part of the annual take consists of wild-caught animals. Together, the red, cross, silver, blue, and white foxes produce almost as much revenue as all other fur animals combined. The annual cateh excerds 35,000 pelts, valued at more than $\$ 1,000,000$.

\section{BEAVER}

The beaver, one of Alaska's most important fur animals, is well distributed throughout the mainland river valleys (fig. 21) wherever its farorite foods, the cottonwoods and willows, grow. Beaver 


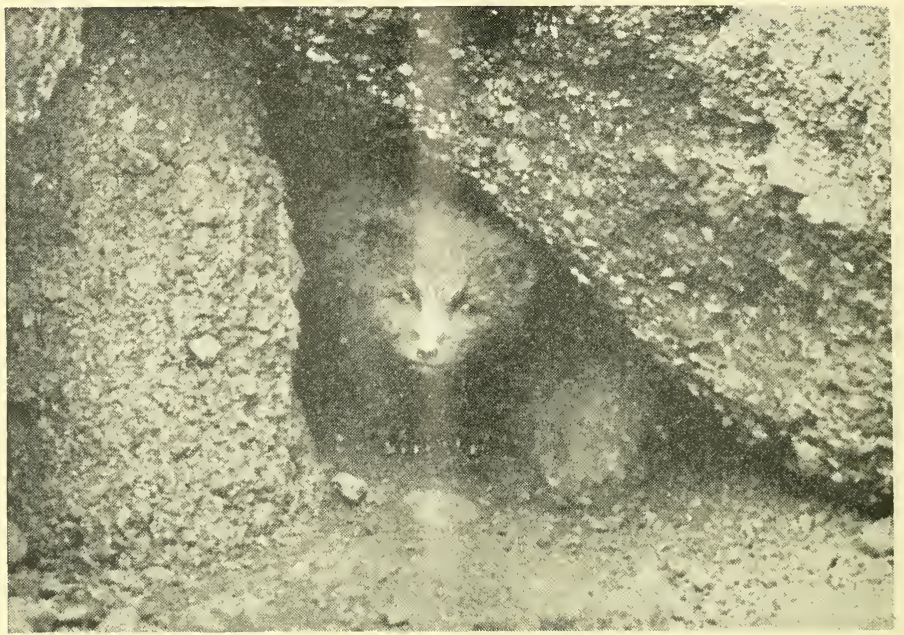

B58446

Figure 20.-Blue fox at entrance to den, Amchitka Island. (Photo by Frank Dufresue.)

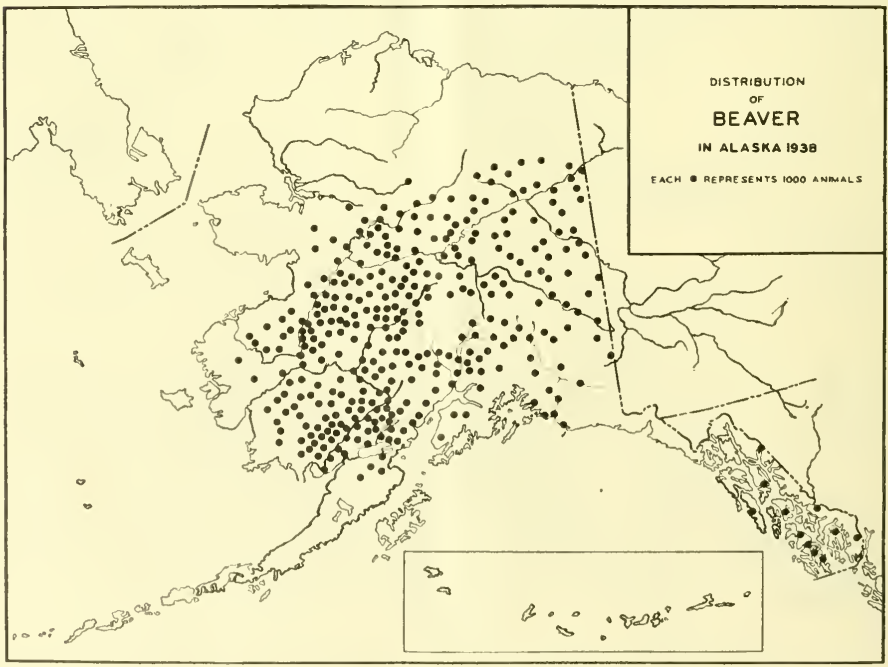

B8272M

Figulze 21.-Distribution of the beaver. 
dams and houses are particularly abundant in the Bristol Bay and Kuskokwim watersheds. The beaver population of Alaska is well above 200,000 , and the anmual cash return received for the pelts taken by trappers amounts to nearly $\$ 250,000$.

\section{MUSKRAT}

Muskrats are the most abundant of all fur animals in Mlaska. The annual crop, exceeding 250,000 pelts, is valued at more than $\$ 220,000$. Wherever deltas are formed, muskrats are found in great mumbers (fig. 22). Oecasional severe winters that freeze ponds to the bottom

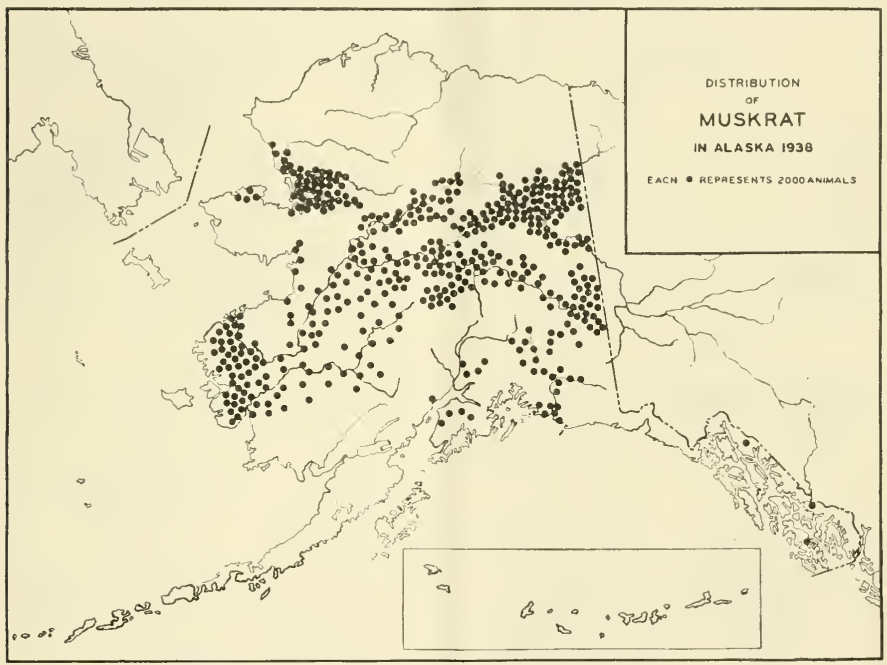

Figure 22.-Distribution of the muskrat.

bring about periods of scareity, but on the whole the muskrat crop is very steady.

\section{LYNX}

The soft, gray fur of the Canadian lynx is a choice item of trade, and when this animal reaches periodic peaks of abundance in Alaska (fig. 23), it serves to bring about a condition of comparative wealth among the trappers. The staple food of the lynx comes from the ranks of the snowshoe hares; hence its numbers fluctuate in response to the rabbit cycle. For instance, the catch was only 318 pelts in 1921, but it mounted swiftly to the record high of 10,173 in 1928 . The average annual eatch over a 16 -year period was 3,817 pelts, valued at about $\$ 130,000$. 


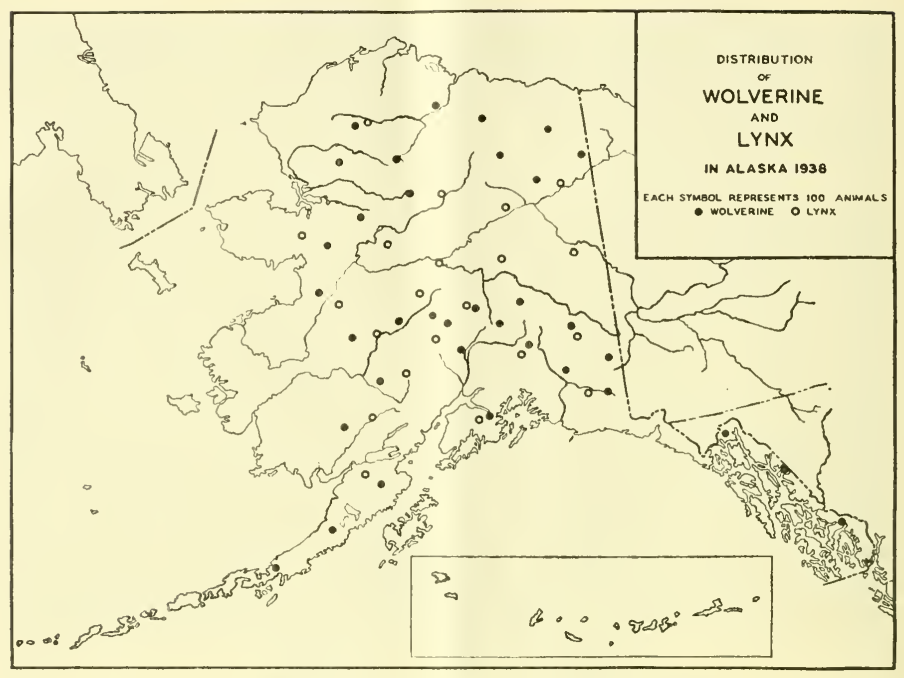

Frgure 23.- Distribution of the wolverine and the lynx.

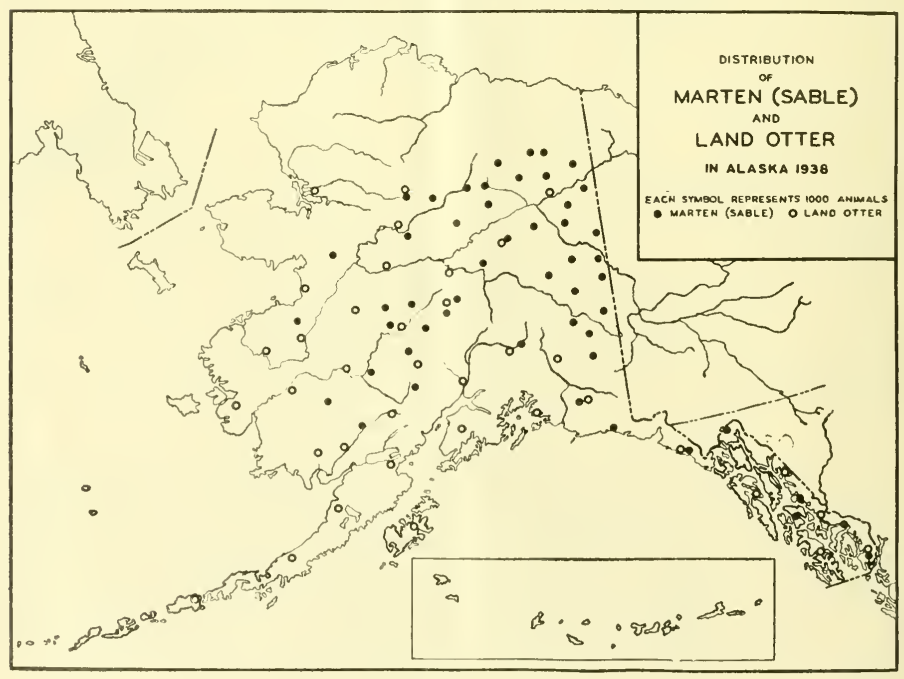

B8269M

Figure 24.-Distribution of the marten (sable) and the land otter. 


\section{MARTEN}

The American marten, or sable, is generally distributed throughout timbered parts of the Territory (fig. 24), usually in areas frequented by the common red squirrel, upon which it largely preys. Although this beautiful fur animal has become alarmingly scarce over most of its range, special action by the Alaska Game Commission has prevented depletion in the Territory. Owing to the high value of its pelt, closed seasons are necessary to preserve the species. The animal has a fatal curiosity concerning traps, so is probably taken to some extent even in closed seasons in sets for other animals. The number of marten pelts exported from Alaska varies greatly from year to year (according to the closed seasons), but the anmual average for 16 years was 4,314 , valued at more than $\$ 90,000$.

\section{LAND OTTER}

The land otter has never been plentiful in Alaska, although it ranges from the southeastern sea coast to the Aretic Circle (fig. 24). Over a period of many years, the average ammal catch has been about 3,000 , valued at more than $\$ 50,000$. Two types of pelts are recognized by the fur trade: the large blue-brown pelt from the coast, and the smaller silky pelt from interior rivers. Both are of excellent quality.

\section{WEASEL}

Weasels, source of the fur known as ermine, are widely scattered (fig. 25) in Alaska, but the gathering of their white pelts is of small

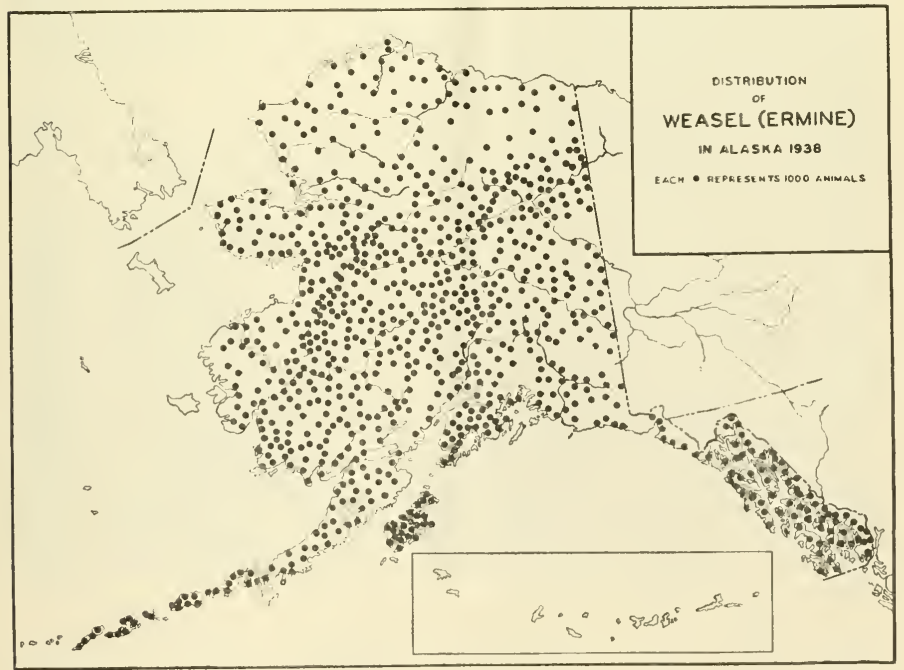

FIGURE 25.-Distribution of the weasel (ermine).

B8270M 
importance. The average annual catch of about 12,000 has remained unchanged for many years.

\section{WOLVERINE}

With the exeeption of the Northwest Territory of Canada, Alaska probably has more wolverines than all other sections of the continent. They are not plentiful in any one section but are widely distrib uted (fig. 23) in rugged mountain areas where man scldom travels. The annual catch over a period of 16 years averaged 420 polts, valued at more than $\$ 5,000$.

\section{POLAR BEAR}

The polar bear is classed as a fur animal under the Alaska game law, but few pelts are exported. Eskimos of the Arctic coast relish the flesh of this huge beast and find many local use's for the hide. About 65 skins, valued at $\$ 40$ each, are exported each year.

\section{OTHER FUR ANIMALS}

Marmots, ground squirrels, tree squirrels, and Arctic and snowshoe hares are relatively unimportant so far as the sale value of their polts is concerned. About $\$ 300$ worth find their way to the fur markets each year. These small species are an important source of food for other fur animals and are utilized locally for human food and clothing. Wolves and coyotes, though not strictly classed as fur animals, liave pelts of sufficient value to return about $\$ 14,000$ ammully to trappers as an important byproduct of predatory-animal control operations.

\section{SEA MAMMALS}

The waters bordering Alaska contain striking varieties and profuse numbers of mammals that have always greatly exeited the interest of explorers. The sea otter, or "old man of the sea," is most often mentioned because of its many humanlike traits and the great value of its fur (fig. 26). The roaring of sea lions is frequently alluded to by chroniclers, as well as the whistling neigh of the walrus, or valross, the Norwegian "sea horse." The fur seal has compelled attention by sheer woight of numbers and by the value of its silken pelt. It is noteworthy that Alaska's first naturalist, George Wilhelm Steller, even while he watched his commander, Vitus Bering, slowly dying in 1741 while shipweeked on the island that now bears his name, found time to describe the sea cow, a huge kclp-cating mammal the like of which no naturalist ever laid cyes upon before or since. This almost mythical brast lives only in Stcller's vivid deseription, and the only conerete evidence of the quondam existence of this great animal is in a few skins and skeletons in musenms.

The world's largest and most valuable fur seal herel, which migrates 'very summer to the Pribilof Islands, today is estimated to contain upwards of $2,000,000$ animals (fig. 27). The walrus of the northeru 


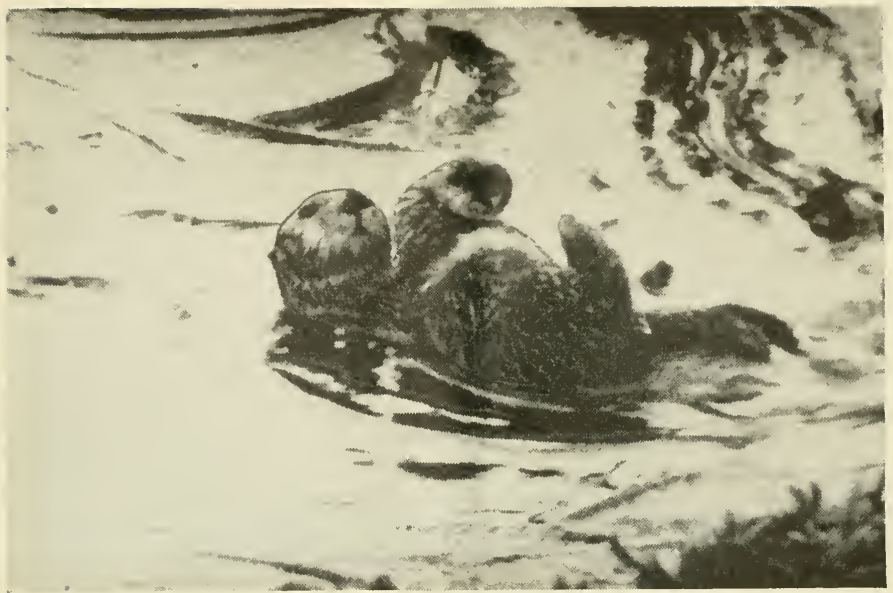

B53443

Figure 26.--Mother sea otter and young, Oglinga Island. Photo by Homer Jewell.)

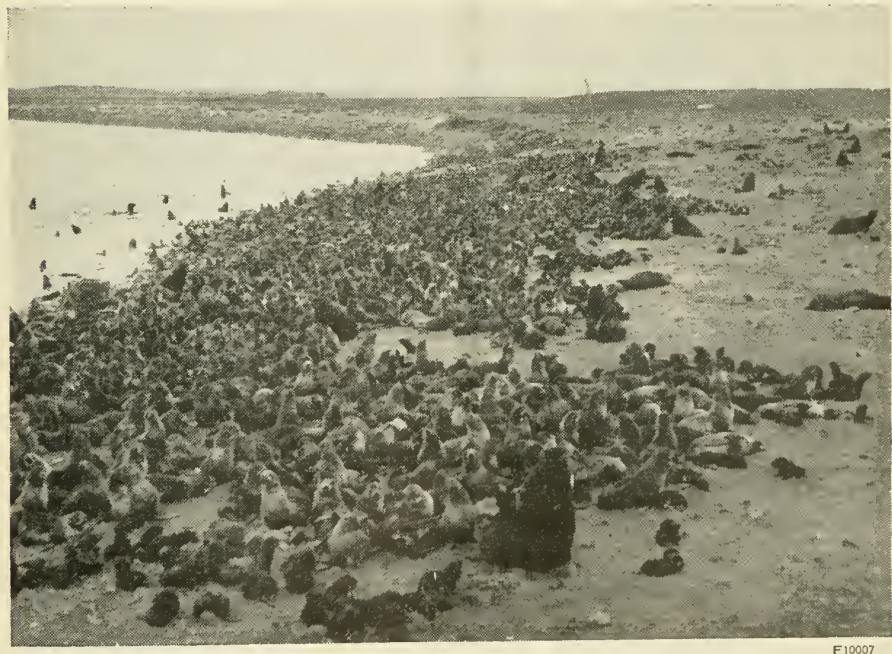

Figure 27.-Fur seal herd on Polovina rookery, St. Paul Islaud.

(Photo by H. B. Carr.) 
Bering Sea and Arctic Ocean ice floes still exists in tens of thousands. Along the Aleutians and farther south, sea lion rookeries are common. The hair seals are represented by four species: the harbor seal, ringed seal, ribbon seal, and the large bearded seal, or "oogruk," of Eskimo lore.

The most valuable individually of all the sea mammals-once feared to have vanished entirely - is the sea otter. To the early-day Russians the glistening fur of this animal was sought almost to the exclusion of all other kinds, and the ruthless slaughter did not stop even when the Territory passed to the United States. The sea otter owes its existence to the fact that its few survivors became so scattered over the foggy, storm-tossed waters of the Aleutian Islands that they escaped detection for more than a quarter of a century; all killing has been prohibited since 1911. Now, this miraculously preserved "old man of the sea" is doubtless saved to posterity and assured of absolute protection for many years.

Alaska waters have always been rich in cetacean life. There are six varieties of large commercial whales: the Pacific right, bowhead, finback, humpback, sperm, and sulphur-bottom or blue whales, the last-named being the largest of all living creatures; four or five species of smaller whales, including the grampus, blackfish, and killer whales; and several kinds of dolphins and porpoises, among them the milk-white beluga. The gray norwhal, with its single spiral tusk, may be an occasional visitor in the Beaufort Sea.

\section{PREDATORY ANIMALS}

Serious damage is being done to valuable species of big-game animals and game birds by wolves (fig. 28) and coyotes. Wolves have always been present in the Territory, but the coyote has followed the advent of the white man. During the past 25 years this animal has gradually extended its range (fig. 29) and is now so firmly established that it is likely to invade any part of the Territory in which it can find an adequate food supply and is already destructive in the nesting areals of wild ducks and geese. The wolf also preys upon the reindeer of the Bering Sea and Arctic coasts, particularly in herds owned and controlled by native Eskimos, who are now dependent on these animals for a large part of their livelihood.

\section{MAMMALS AS FOOD FOR WILDLIFE}

The fur catch of the predaceous land fur animals in Alaska rises and falls with the abundance of small rodents, among which they obtain their principal food supply. Signs of field mice and lemmings, tree squirrels, and snowshoe hares in spring and summer have proved a reliable basis for foreeasting the next winter's eatch of lynxes, martens, and foxes. Shrews of numerous kinds, conies or pikas, and red-backed 


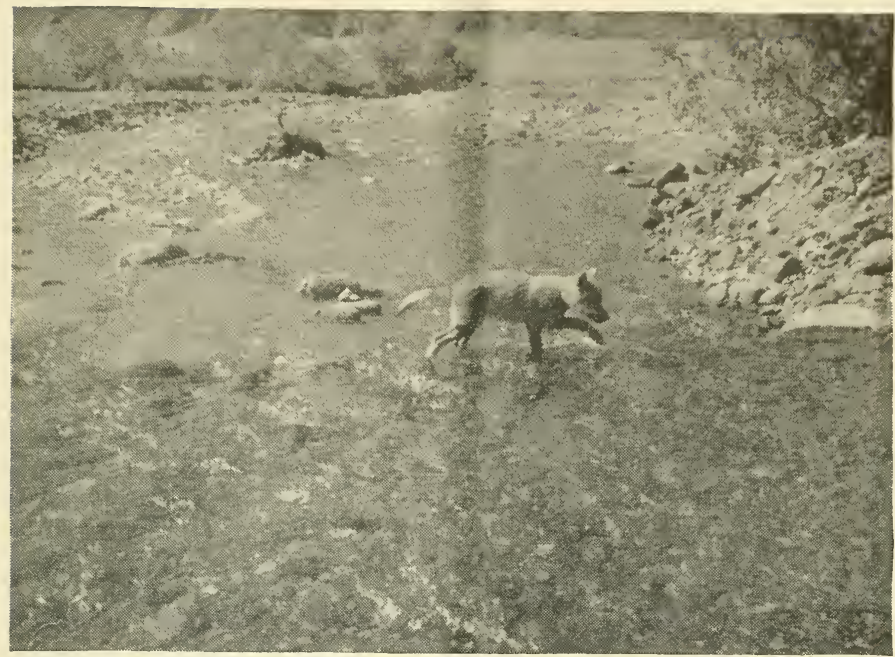

860172

Figure 28.-Wolf pup in Mount MeKinley National Park. (Photo by Ira N. Gabrielson.)

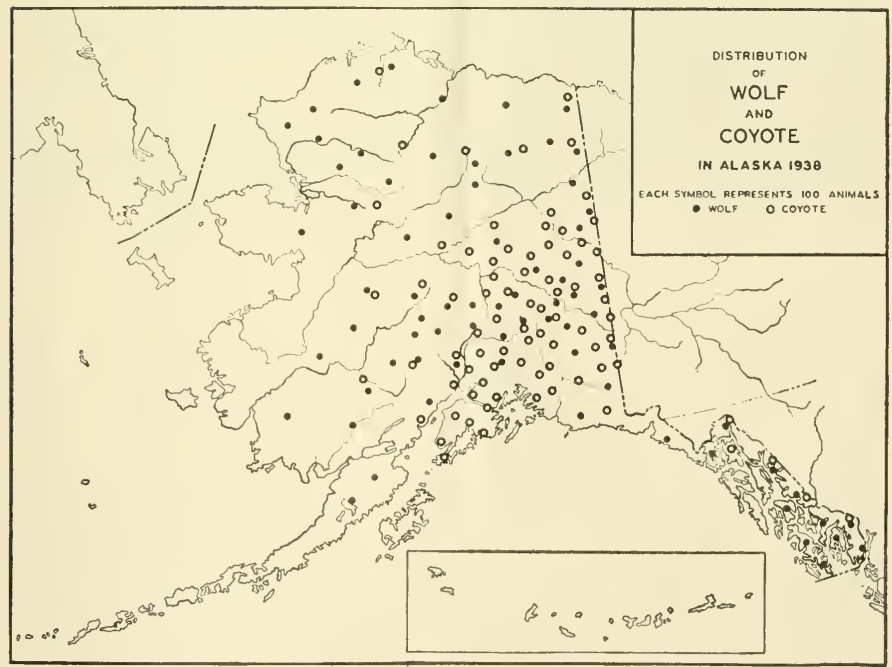

68231M

Figure 29.-Distribution of the wolf and the coyote. 
mice, jumping mice, ground squirrels, flying squirrels, and other rodents possess real value in Alaska as supporting the fur crop and are not considered pests as in agricultural sections of the United States. In common with snowshoe hares, grouse, and ptarmigans, many of the rodent species in Alaska experience more or less regular epizooties, which reduce them nearly to the vanishing point. Among the rodents, these low periods are often preceded by striking migrations-in the case of the lemmings, thousands of animals have been observed to move out across the polar ice to certain death at sea.

\section{MIGRATORY BIRDS}

On its vast nesting grounds, where waterfowl may rear their broods in comparative safety from the disturbing influence of man, Alaska plays summer host to myriads of valuable migrants. April and May find the winged visitor's arriving to seek their favorite summer homes; September and Octoher see them leave, streaming back across the skies in multiplied numbers, for wintering grounds in the United States and Mexico. Many of the ducks and geese take an eastward route from Alaska into Canada and mingle with the birds of that country before swinging southward.

\section{DUCKS}

The commonest duck in Alaska is the pintail, which is the mainstay of gunners in the Western States. The mallard and the American wigeon are next in numbers, although many green-winged teals and greater and lesser seaups breed in the Territory, as do also smaller populations of ringnecks, shovelers, gadwalls, blue-winged teals, and canvasbacks. The salt-water ducks are well represented by the ubiquitous oldsquaw, with its organlike voice, and by the white-winged, surf, and American scoters. The American and Barrow's goldeneyes also are abundant along the coast line, and the bufllehead and the harlequin are nearly as plentiful. Widespread throughout the Territory are the saw-billed or fish ducks-the American, red-breasted, and hooded mergansers. Nesting along the Aretic and Bering coasts, and migrating southward and westward to Bristol Bay and the Aleutian Islands, are the beautiful eiders, four species in all. The commonest of these is the large Pacific eider, an isolated colony of which nests in the Glacier Bay National Monument in southeastern Alaska. The king eider, the male of which has a characteristic fleshy protuberance on the upper bill, is one of the best known of the four. Well-distribted but not quite so abmelant are the spectacled cider and the tealsized Steller's eider. Rare and beautiful ducks from the other hemisphere occasionally reach Alaska: the European teal is the common nesting teal of the Aleutians, while the European wigeon, the Baikal and falcated teals, the pochard, and the European goldeneye have been taken as stragglers in other parts of the Territory. 


\section{GEESE}

While the occurrence of so many kinds of ducks in Alaska may be surprising, of equal interest is the presence in numbers of various kinds of wild geese, of which there are eight that nest there. Commonest are the three races of the Canada goose, namely, the whitecheeked goose, restricted to the islands of southeastern Alaska (fig. 30); and the lesser Canada goose ant the diminutive cackling goose, which are found over large areas of the northern and western parts. Two varieties of white geese, both with jet black wing tips, visit Alaska; the lesser snow goose and the tiny Ross' goose, the nest of which has only recently been found, for the first time, in the Perry River district,

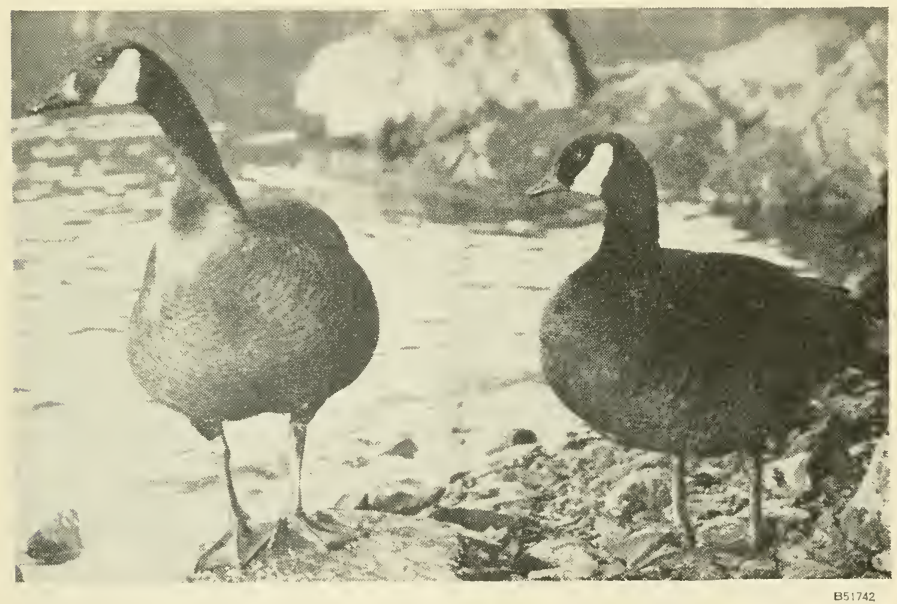

Figure 30.- White-cheeked geese, Chichagof Island. (Photo by Frank Dufresne.)

Northwest Territory, Canada. A common nester throughout western Alaska is the highly favored white-fronted, or speckle-bellied goose, relative of the common graylag of Europe, the reputed progenitor of the domestic goose. Alaska's most beautiful goose, the emperor, never leaves the Territory except as a rare straggler. This slate-blue bird, with white neck and head washed with orange, nests along the Bering Sea tidal lands and winters in the Aleutian Islands. The great flocks of black brant, which form such a striking attraction on the California coast in winter, have their nesting grounds along the western and northern shores of Alaska. To the Eskimos, the long, waving, cobwebby patterns of these birds heading northward over the broken ice floes heralds spring and their equally impressive southward flight portends the approach of winter. 


\section{OTHER MIGRANTS}

Among water birds that are protected at all times are the whistling swan and the little brown crane, both of which are plentiful in the Territory and are becoming more so with each passing year.

There is an amazing number and variety of shorebirds in Alaska, including the black oystercatcher, golden and black-bellied plovers, surfbirds, turnstones, Wilson's snipe, dowitcher, Hudsonian and bristle-thighed curlews, wandering tattler, greater and lesser yellowlegs, knot, Pacific godwit, and northern and red phalaropes, as well as numerous sandpipers. Attracted to the great number of lakes and waterways in the Territory is a profusion of gulls, jaegers, terns, loons, rormorants, grebes, blue herons, and other nongame birds.

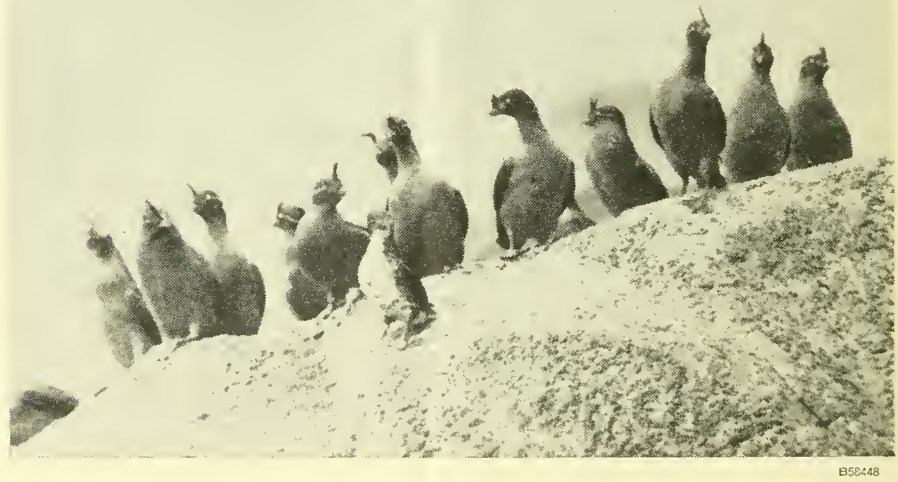

Figure 31.-Auklets on the Aleutian Islands. (Photo by H. Douglas Gray.)

SEA BIRDS

Literally millions of sea birds frequent the rocky islands and rugged headlands of Alaska each summer to rear their young. Colonies of murres, auklets (fig. 31), kittiwakes, guillemots, puffins, petrels, albatrosses, fulmars, and shearwaters (fig. 32) fill the seascape with abundant life.

\section{NATIVE UPLAND GAME BIRDS}

In aldition to such well-known forms of grouse as the ruffed and sharp-tailed and the less familiar spruce and sooty grouse, Alaska has three varieties that turn white in winter. These white grouse, or ptarmigans, in furnishing practically the only meat diet at times available to explorers, mineral prospectors, and trappers, have played an 
important part in the settling of northern Alaska. As a result of their year-round occurrence in the Territory, the white grouse are held in high regard by old-time residents.

Probably the most abundant of upland game birds is the willow ptarmigan, which lives in most of the willow-grown sections of the Territory and sometimes forms flocks so large as to obseure the sun when they take to the air with a thunderous roar of wings. Flocks of 10,000 to 20,000 have been recorded during periods of high populations. The rock ptarmigan (fig. 33), slightly smaller in size, is found at greater elevations, and the white-tailed ptarmigan, not much larger than the domestic pigeon, rarely descends from the extremely high peaks.

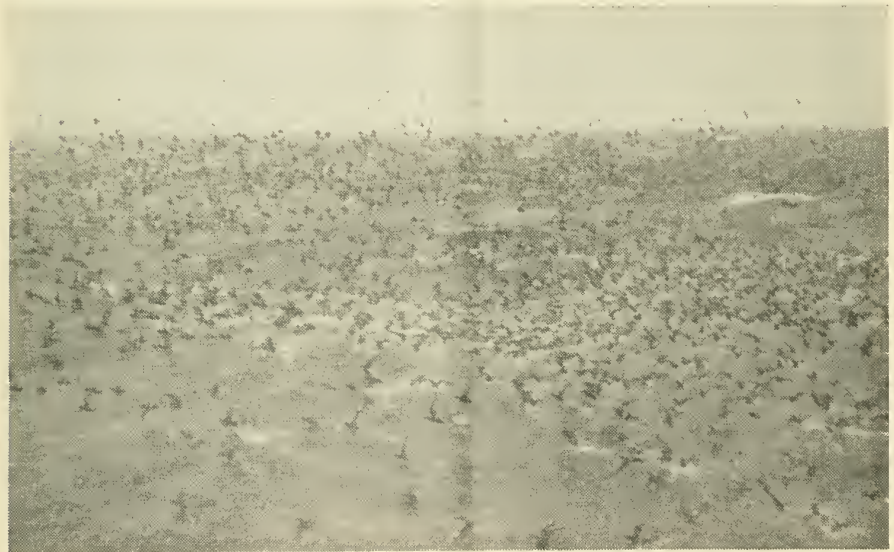

F 10064

Figure 32.-Shearwaters in Bering Sea. (Photo by H. B. Carr.)

In summer, the ptarmigans are colored various shades of brown and gray, more or less in harmony with the natural background, but in winter the plumage becomes pure white except for the black unclertail coverts in the willow and rock species. Early in fall the flesh of these birds has a delieate flavor as a result of their diet of mountain blueberries, cranberries, and grass sceds, but during the long winters, which force them to subsist almost exclusively on willow bucls, the meat becomes quite bitter, although they still afford the lone prospector a welcome change of diet from his monotonous fare of bacon and beans.

It is unfortunate that the Alaska grouse, including ptarmigans, periodically die off from epizootic disease. Thus, these birds increase to great abundance every 8 to 10 years and then are stricken almost 
to the vanishing point, after which the flocks slowly build up again from scattered survivors.

As a result of the uncertainty of the native game-bird crop, experiments on a limited scale are being made with hardy types of pheasants, including the brown and blue eared, cheer, kaleege, Mongolian, and Reeves'. It is the plan to rear and liberate in various parts of the Territory enough of these birds to determine which if any will survive the rigors of the Alaska winters.

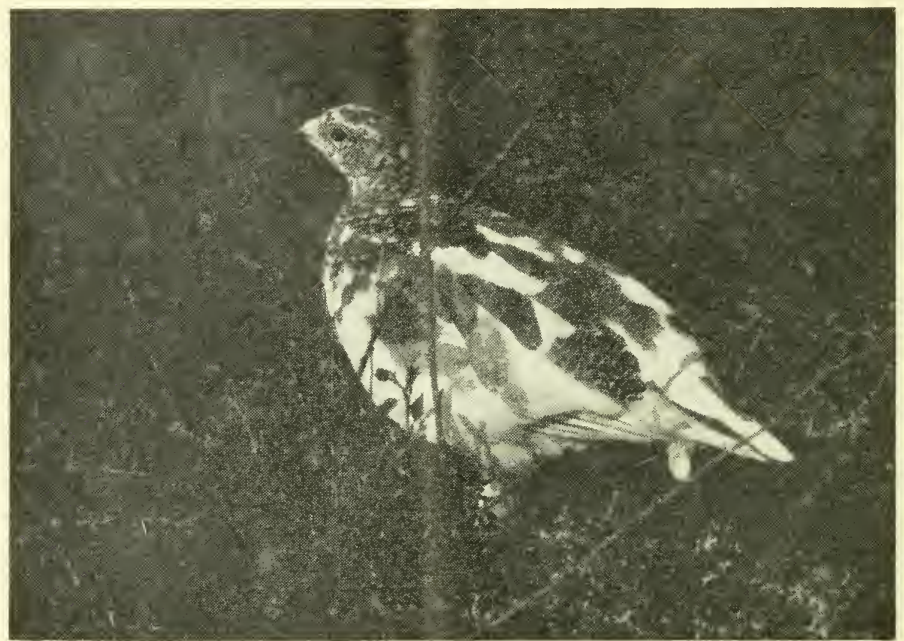

B24 150

Figure 33.-Rock ptarmigan in partial winter plumage, Twelve Mile Creek. (Photo by O. J. Murie.)

\section{BIRDS OF PREY}

Largest of Alaska's birds of prey are the bald eagle, which is abundant along the coast line, and the golden eagle, scattered throughout the interior mountain ranges. In the far north the black and white gyrfalcons are often found in the vicinity of the ptarmigan flocks upon which they prey. Frequenting the northern tundra is the snowy owl, as well as the migratory short-eared owl. In timbered sections are the great gray owl, great horned owl, hawk owl, Richardson's owl, and the small pygmy and screech owls. Among the hawks, the goshawk and the red-tailed hawk are most often seen, although the duck hawk, rough-legged hawk, osprey, sparrow hawk, sharp-shinned hawk, pigeon hawk, and marsh hawk also are familiar sights. 


\section{SONG BIRDS}

The song birds of Alaska include an unusual number and variety of thrushes, the most common of which is undoubtedly the western robin. Bird students are generally amazed to find in these latitudes such a wide assortment not only of thrushes but also of warblers, sparrows, vireos, swallows, wrens, kinglets, crossbills, chickadees, flycatchers, finches, juncos, red polls, waxwings, woodpeckers, bluebirds, hummingbirds, snow buntings, longspurs, pine grosbeaks, fliekers, phoebes, blackbirds, pipits, and siskins. The sprightly water ousel, or dipper', is a 'ommon sight along the mountain streams. Among the distinetive birds of somewhat larger size are the bole Alaska jay, the dark-blue Steller's jay, and the black-and-white mag-

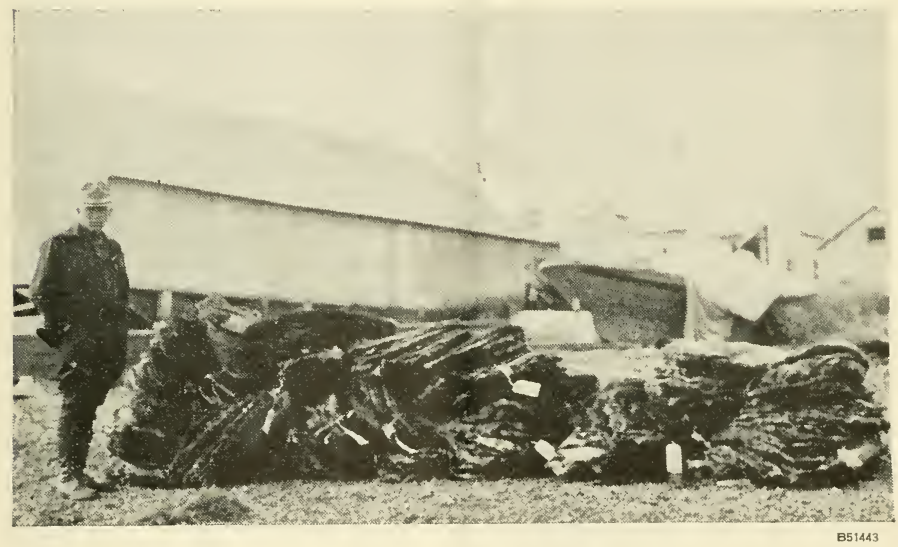

Figure 34.-Contraband beaver pelts valued at $\$ 7,000$ seized by wildife agents of the Alaska Game Commission. (Photo by Homer Jewell.)

pie. The northern shrike and the kingfisher are well distributed. Around the villages, the northern raven and northwest crow are common seavengers.

\section{PROTECTION GIVEN WILDLIFE}

For many years, game-law enforcement in Alaska was a somewhat haphazard undertaking, divided among several Federal agencies delegated by Congress to administer laws that were inadequate and had gradually become obsolete and impracticable of enforcement. Under these conditions, both game and land fur animals were diminishing in numbers in many sections. The intensive killing of beavers (fig. 34) and the overtrapping of martens endangered the future of these valuable species. It was highly important that the Government 
exereise better guardianship of this last great retreat for wildlife, to safeguard the interests of the large native populations and to assure perpetuation of the varions species (fig. 35).

The passage of the Alaska Game Law in 1925 set up a game commission to function as the operating agency of the Bureau of Biological Survey (now the Fish and Wildlife Service) in the formation and enforcement of suitable regulations for managing the wildlife resources in the Territory. The Alaska Game Law, as modified by Federal reorganization, provides that the Secretary of the Interior shall appoint a resident game commission composed of five members, of whom four, not Federal employees, are required to come, one each, from the four judicial divisions, and the fifth member, the Executive officer of the commission, to be the resident representative of the Fish and Wildlife Service. This law makes its general administration the responsibility of the commission and also provides that, upon consultation with or upon recommendation from the commission, the Secretary of the Interior may issue suitable regulations governing the taking of game animals, land fur-bearing animals, and birds in Alaska.

The Alaska Game Commission meets annually, at which time it proposes, for action by the Fish and Wildlife Scrvice and the Secretary of the Interior, suitable regulations with respect to hunting seasons, bag limits, establishment of game and fur districts, and designation of areas as wildlife sanctuaries. It formulates general plans for regulatory work to be carried out under the direct supervision of the executive officer and makes recommendations for action on such matters as restocking game lands, introducing new species, controlling predatory animals, and undertaking wildlife research. The work of the commission has brought about a wholesome respect for the game laws and widespread cooperation in their enforcement from the residents of the Territory, both natives and whites. The Fish and Wildlife Service, in close cooperation with the commission, conducts research in the Territory with the objective of deternining the best means of developing and maintaining the wildlife resources.

\section{REGISTERED-GUIDE SERVICE FOR SPORTSMEN}

From all parts of the world sportsmen come to Alaska seeking big-game trophies (table 2), some of the speeies not to be had in any other region. To care for this type of visitor, a registered-guide service has been made available and license fees have been preseribed under direction of the Alaska Game Commission. The foes for nonresidents and aliens are as follows: Nonresident small-game license, $\$ 10$; nonresident general-hunting license, $\$ 50$; and alien license, $\$ 100$. No additional fee is charged nonresident hunters in comnection with trophies taken or transported out of the Territory. 
TABLE 2.-Measurements of outstanding game trophies taken in Alaska by nonresident hunters

BROWN BEAR-SKIN AND SKULL

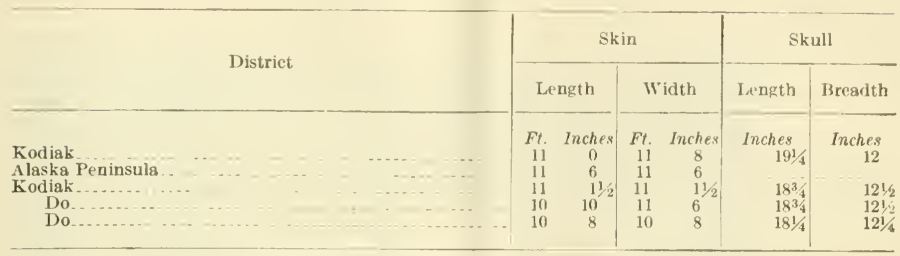

GRIZZLY BEAR-SKIN AND SKULL

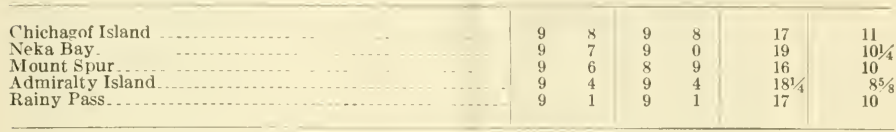

BLACK BEAR-SKIN AND SKULL

Hobart Bay

Kupreanof

Southeastern Alaska

Dunean Canal.

Do..............

\begin{tabular}{ll|ll|l|l|}
7 & 9 & 7 & 8 & & \\
7 & 5 & 7 & 4 & 14 & 10 \\
7 & $31 / 2$ & 7 & $31 / 2$ & $13^{1 / 2}$ & $141 / 2$ \\
7 & 2 & 7 & 6 & $121 / 4$ & 7 \\
7 & 2 & 7 & 2 & $117 / 8$ & $71 / 4$ \\
\hline
\end{tabular}

MOUNTAIN SHEEP-HORNS

District

Kenai

Rainy Pass

Upper Tanana

Kenai.

Rainy Pass.

\begin{tabular}{|c|c|c|c|c|}
\hline \multirow{2}{*}{ Spread } & \multicolumn{2}{|c|}{ Base } & \multicolumn{2}{|c|}{ Length } \\
\hline & Right & Left & Right & Left \\
\hline $\begin{array}{c}\text { Inches } \\
21 \\
21 \\
277 / 8 \\
261 / 4 \\
21\end{array}$ & $\begin{array}{r}\text { Inches } \\
14^{1} / 4 \\
14^{1} 2 \\
14^{1} / 4 \\
13^{1} / 2 \\
12^{1} 2\end{array}$ & \begin{tabular}{r|} 
Inches \\
$14^{1}$ \\
$14^{1}$ \\
$141_{4}^{1}$ \\
$13^{3}$ \\
$12^{1}$ \\
\end{tabular} & $\begin{array}{c}\text { Inches } \\
401 / 2 \\
39 \\
45 \\
45^{1} / 2 \\
4312\end{array}$ & $\begin{array}{c}\text { Inches } \\
45 \\
391 \\
431 / 4 \\
461 \\
431\end{array}$ \\
\hline
\end{tabular}

MOENTAIN GOAT-HORNS

District

Richardson Highway

Tracy Arm.

Do
LeConte Bay.

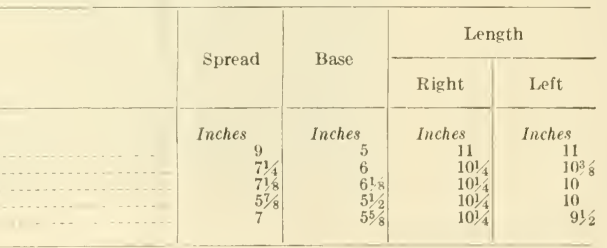

\section{MOOSE-ANTLERS}

Distriet

Rainy Pass

Kenai.

Do.

Do.
Do.

\begin{tabular}{|c|c|c|c|c|}
\hline \multirow{2}{*}{ Sipread } & \multicolumn{2}{|c|}{ Palm } & \multicolumn{2}{|c|}{ Points } \\
\hline & Right & Left & Right & Left \\
\hline $\begin{array}{c}\text { Inches } \\
731 / 2 \\
70^{1} / 4 \\
70 \\
70 \\
70\end{array}$ & $\begin{array}{c}\text { Inches } \\
\qquad \begin{array}{c}13 \\
161 / 2 \\
161 / 2 \\
15\end{array}\end{array}$ & $\begin{array}{c}\text { Inches } \\
18 \\
151 / 2 \\
0\end{array}$ & $\begin{array}{r}\text { Number } \\
11 \\
25 \\
22 \\
15 \\
16\end{array}$ & $\begin{array}{r}\text { Number } \\
8 \\
23 \\
18 \\
14 \\
18\end{array}$ \\
\hline
\end{tabular}


TABLE 2.- Measurements of outstanding game trophies taken in Alaska by nonresident hunters-Continued

CARIBOU-ANTLERS

\begin{tabular}{|c|c|c|c|c|c|c|c|}
\hline \multirow{2}{*}{ District } & \multirow{2}{*}{ Spread } & \multicolumn{2}{|c|}{ Beam } & \multicolumn{2}{|c|}{ Brow tines } & \multicolumn{2}{|c|}{ Points } \\
\hline & & Right & Left & Right & Left & Right & Left \\
\hline $\begin{array}{c}\text { Rainy Pass.... } \\
\text { Do } \\
\text { Do } \\
\text { Matanuska } \\
\text { Healy River.... }\end{array}$ & $\begin{array}{c}\text { Inches } \\
59 \\
56^{1} \\
49^{1} \\
48 \\
48\end{array}$ & $\begin{array}{c}\text { Inches } \\
57^{1} / 2 \\
611^{1} \\
57 \\
561 / 2 \\
52\end{array}$ & $\begin{array}{c}\text { Inches } \\
58 \\
60 \\
58 \\
575 / 8 \\
501 \%\end{array}$ & $\begin{array}{c}\text { Inches } \\
24 \\
\\
20 \\
24 \\
53 / 4\end{array}$ & $\begin{array}{c}\text { Inches } \\
23 \\
20^{1} \\
19 \\
23^{1} \\
151 / 4\end{array}$ & $\begin{array}{r}\text { Number } \\
15 \\
12 \\
15 \\
12 \\
11\end{array}$ & $\begin{array}{r}\text { Number } \\
18 \\
15 \\
11 \\
10 \\
15\end{array}$ \\
\hline
\end{tabular}

Each nonresident or alien hunter of big game is required by the law to be accompanied by a registered guide. These guides are highclass outdoor men. In addition to arranging the hunting, heading the party in the field, locating the game, and adrising on the selection of suitable trophies, they must also be expert in skinning animals and in preparing and curing the trophies under ficld conditions. At the close of the hunt it usually devolves upon them to pack the skins, capes, and antlers properly and attend to the shipment.

After deciding in what section he wishes to hunt, the sportsman should get in touch with a registered guide or a guide association serving that district and agree upon rates, length of hunt, trophies desired, and other matters. This should be done well ahead of time so that the guide or guide association may make satisfactory arrangements, as many of the hunts require expert preparation. Current lists of registered guides and copies of the Alaska Game Law and the regulations governing open seasons and bag limits for hunting and trapping may be obtained free by writing to the Alaska Game Commission, Juneau, Alaska. 

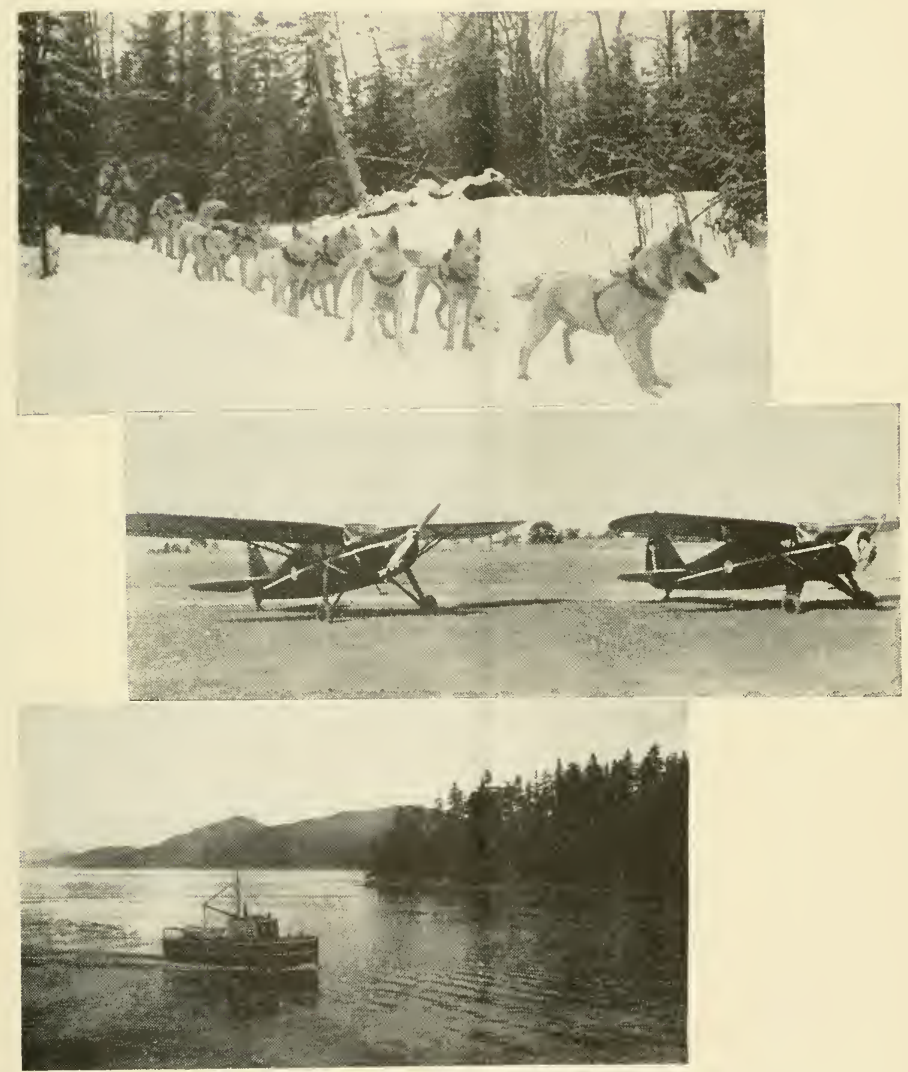

B58623: B8237M: AGC-9

Figure 35.-By land, air, and water, wildlife agents of the Alaska Game Commission protect a valuable wilderness heritage. Upper: White Siberian dog team. (Photo by Frank Dufresne.) Middle: Planes used in patrol by wildlife agents. Lower: The Commission's patrol vessel Marten. (Photo by George Nelson.) 



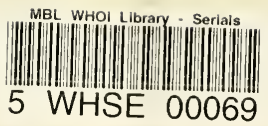


